بررسى شاخصهاى خطاى عملكرد مديريت تحويل آب در طرح تجهيز و نوسازى اراضى شاليزارى

بابكى مؤمنى "، محسن مسعوديان'، محمد على غلامى ' و عليرضا عمادى

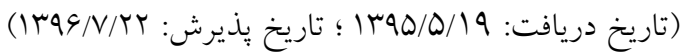

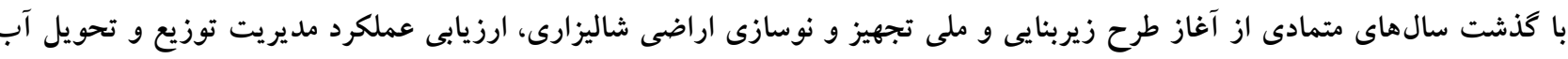

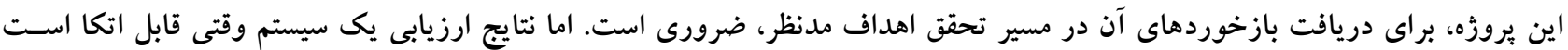

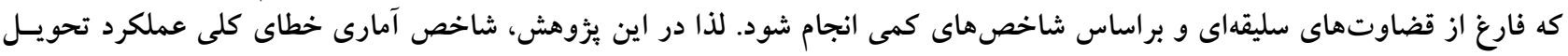

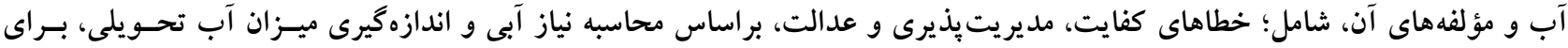

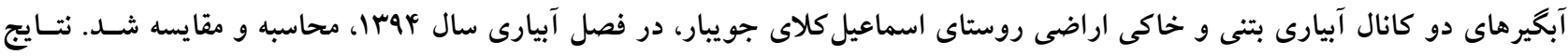

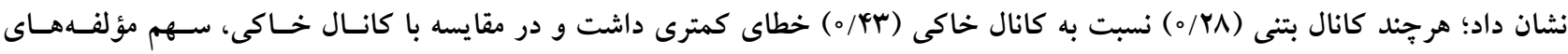

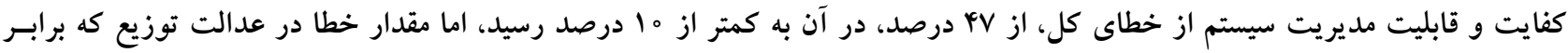

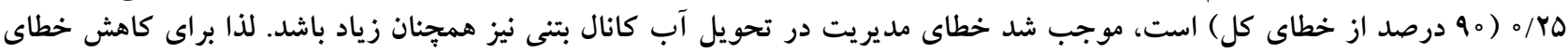

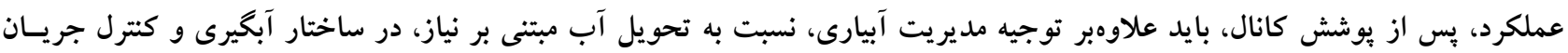
هم بازنخرى شود.

وازههاى كليدى: ارزيابى عملكرد، برنج، سيستم تحويل آب، كفايت، مديريت يذيرى، عدالت

1. كروه كشاورزى، دانشخاه بيام نور، تهران، ايران

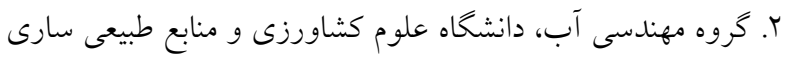

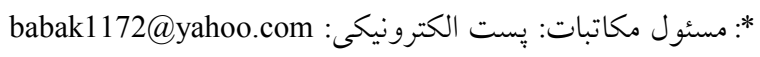


ديخر زهكش قرار مسى گيـرد (شكل ا- ب). بنـابراين انتظـار

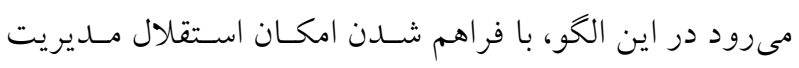

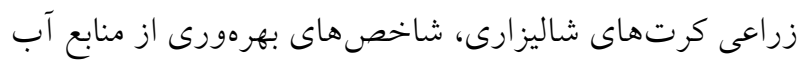

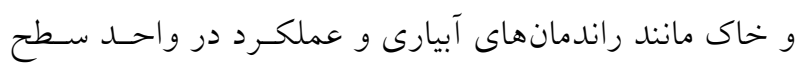

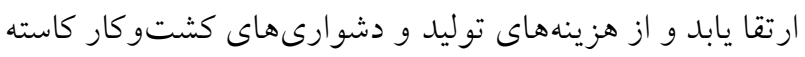

كانالهاى آبيارى مزرعه در طرح تجهيز و نوسـازى اراضى

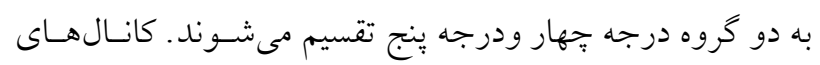

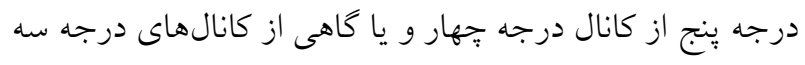
منشعب شده و آب را بين كرتهاى زراعى توزيع مى كنتــ (A).

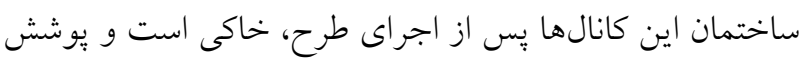

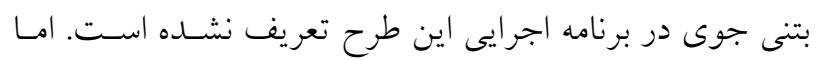

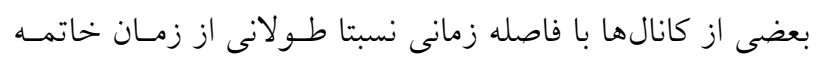

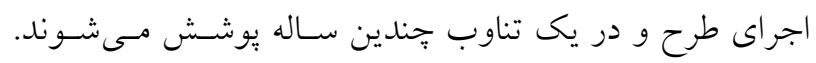

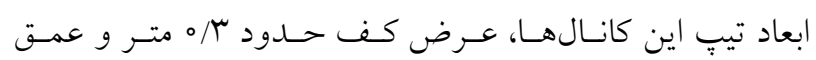

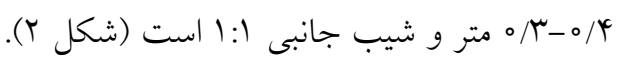
يس از اجراى يروزههـايى نظيـــ تجهيـز و نوسـازى اراضى

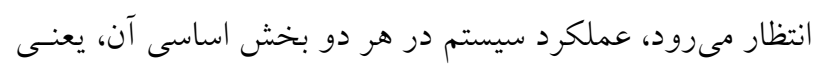

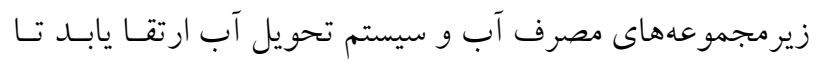
نتايج آن را بتوان بهترتيب در رشد محصول ملات منطقه آبيارى شده

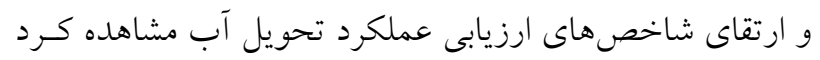

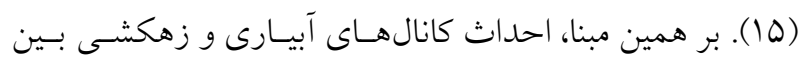

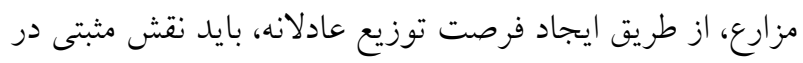

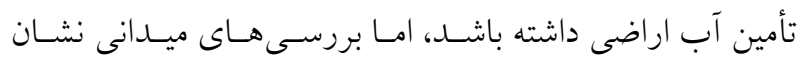

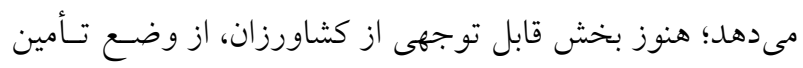

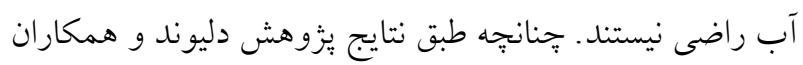

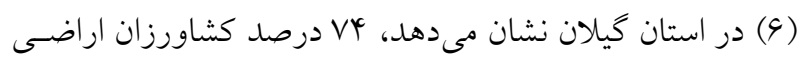

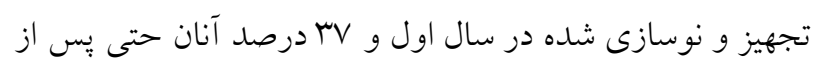

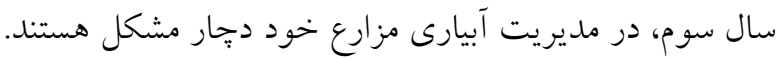
بررسى هاى انجام شده روى يروزههـاى تجهيـز و نوسـازى اراضى شاليزارى اجرا شده نشان مىدهد كه منشأ بخش عمدهاى

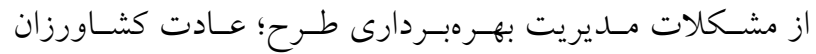

برنج گياهى است كـه نقشسى اساسسى و انكارنايـذير در امنيـت

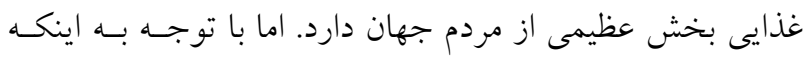

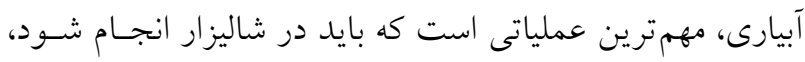

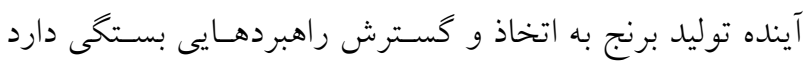
كه آب را به شكلى مؤثرتر در برنامهريزىهـاى آبيـارى اسـتفاده

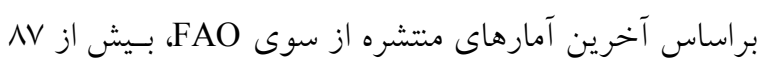

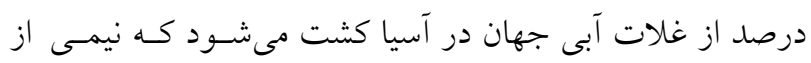

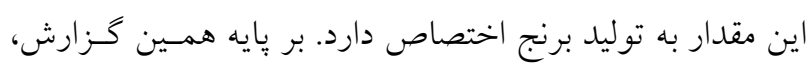

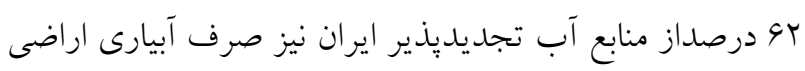

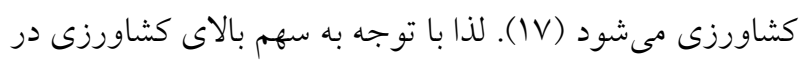

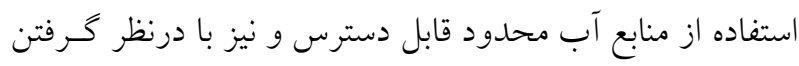

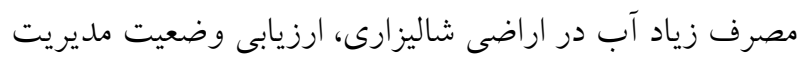
آب در اين اراضى، از اهميت ويزهاى برخوردار است است.

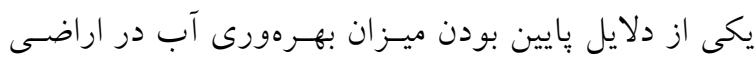

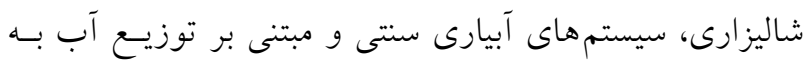

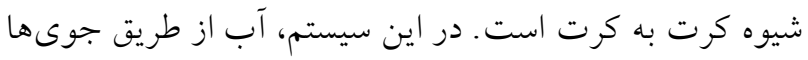

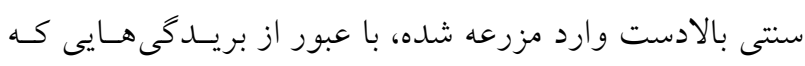

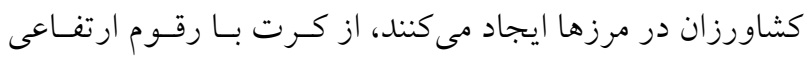

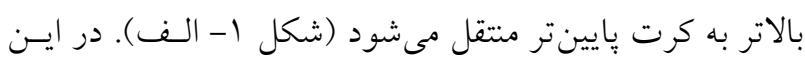

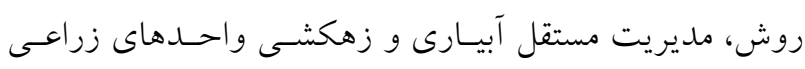

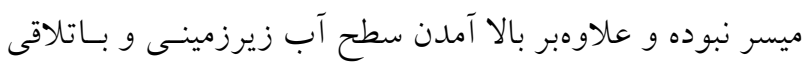

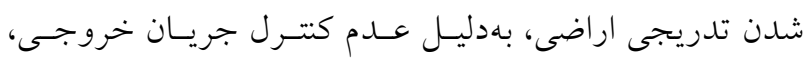

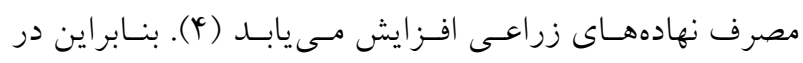
راستاى اصلاح ساختار مديريت آبيارى و زهكشى و هميجنسين

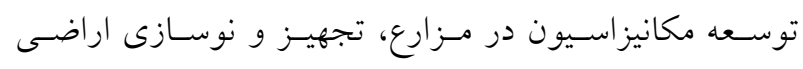

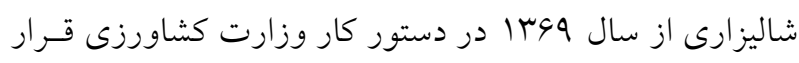

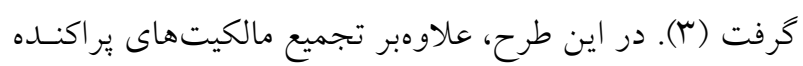

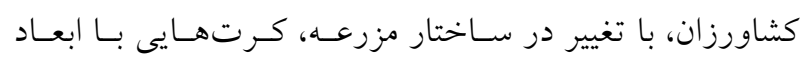

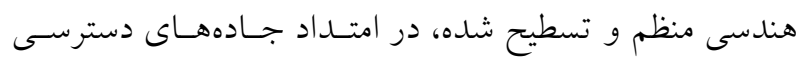

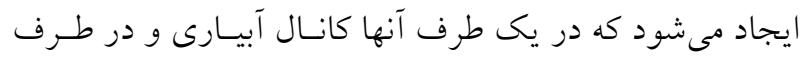




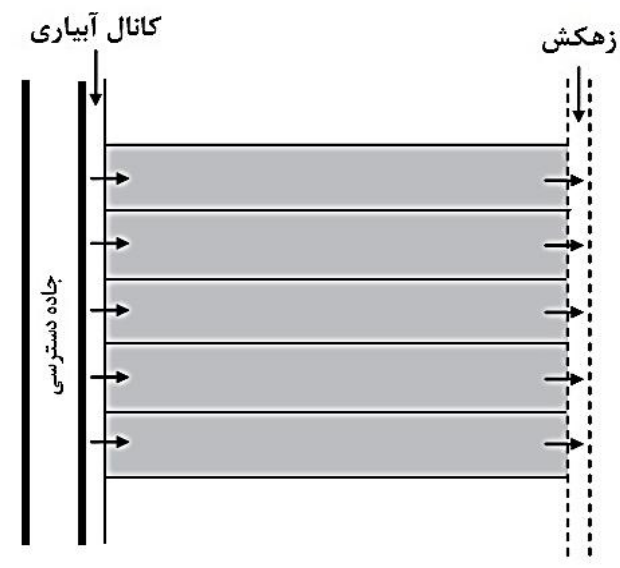

ب) روش آبيارى يس از اجراى طرح تجهيز و نوسازى

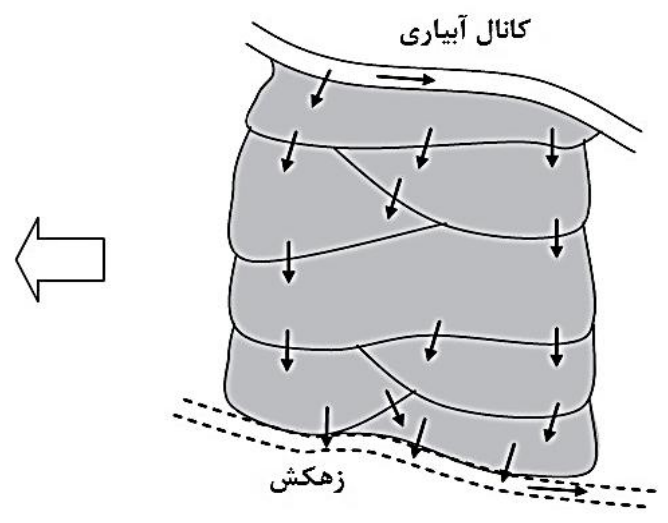

الف) روش آبيارى سنتى كرت به كرت

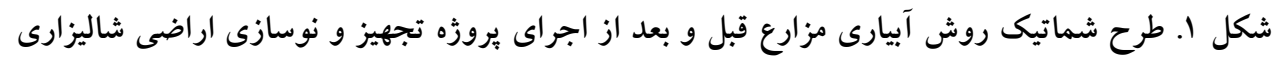

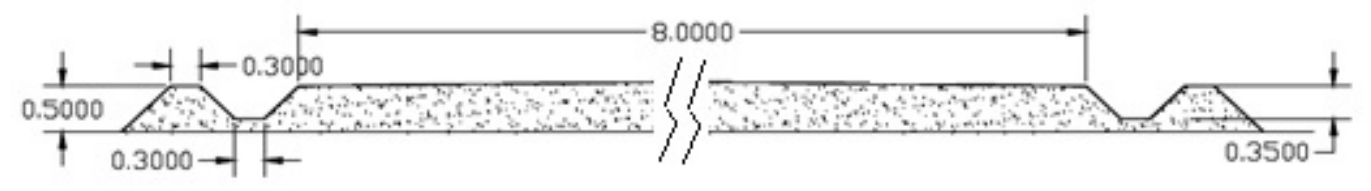

شكل r. مقطع تيبٍ جاده دسترسى و كانال آبيارى كرتهاى شاليزارى در دو طرف آن (rا)

يروزه مورد بررسى قرار گرفته، يا فقط با بهكارگيرى شاخصها و

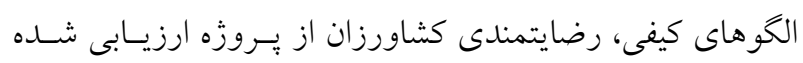

است.

بـا توجـه بـه نقـاط ضـعف تحليـلهـاى كيفى، تعريـف شاخصىهـاى قابـل اعتمـادى كـهـ بتوانــد فـارغ از برخوردهــاى سليقهاى، معيار مناسبى براى قضاوت كارشناسـانه و كمسىسـازى

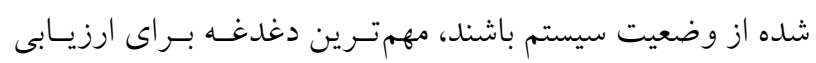

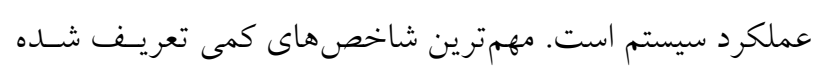
برمبناى اهداف مديريت سيستم تحويـل آب، عبارتنــ از: ميـزان

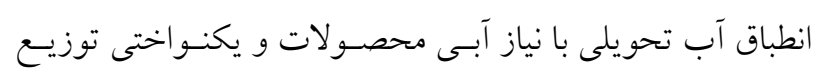

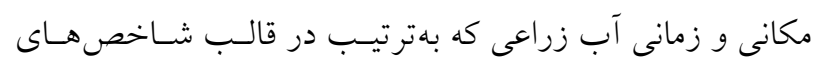

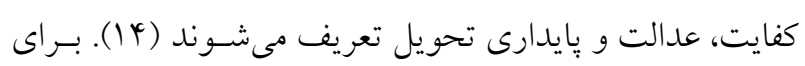
تعريف كمى شاخص هاى مذكور، از فرمولهاى مختلفى استفاده

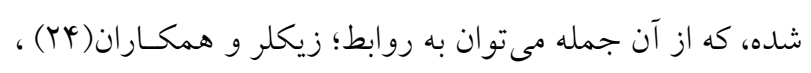
ولر و همكاران (YV)، لنتون (19) و مولدن و گيتس (YY) اشـاره كرد . يكى از شاخص هاى مهم ارايه شـده خطـاى كلى عملكـرد
بالادست به تأمين آب بيشتر، عدم رعايت نسبت ارتفـاعى كـف

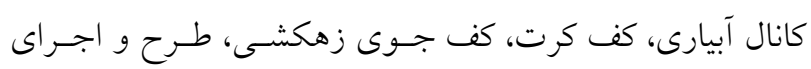
نامناسب مسير كانالها و سازههــاى مربـوط بــه آنهـا اسـت كـهـ موجب شله در بخشىى از مسـير كانـالهـاى خـاكى، هم:جنـان

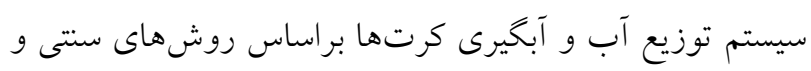

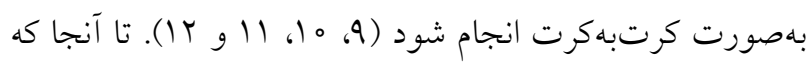

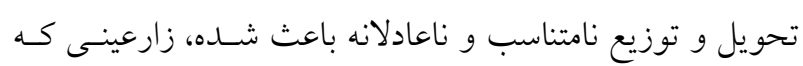
كمتر از نياز اراضى خود آب دريافت كردهاند، بهدنبال راهحل هاى ناي

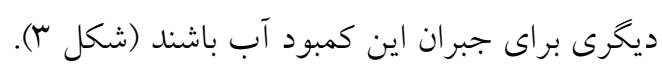
با كذشت بيش از هr سـال از آغـاز عمليـات اجرايسى طـرح تجهيز و نوسازى در اراضى شاليزارى استانهاى شـمالى كشـور،

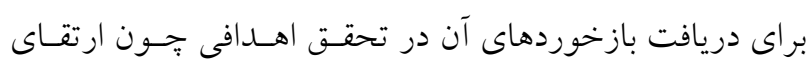
بهرهورى آب و ايجاد بسـترهاى لازم بــراى برنامسهريـزى بويـا و

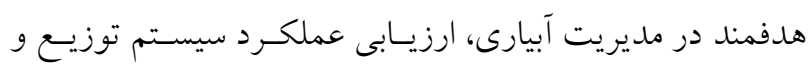
تحويل آب اين طرح، براى متوليان امور، ضرورتى اجتنابنايذير

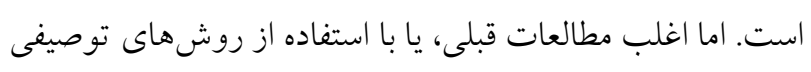
و برمبناى تجربيات كارشناسان بخشهاى مختلف مربوط به اين 


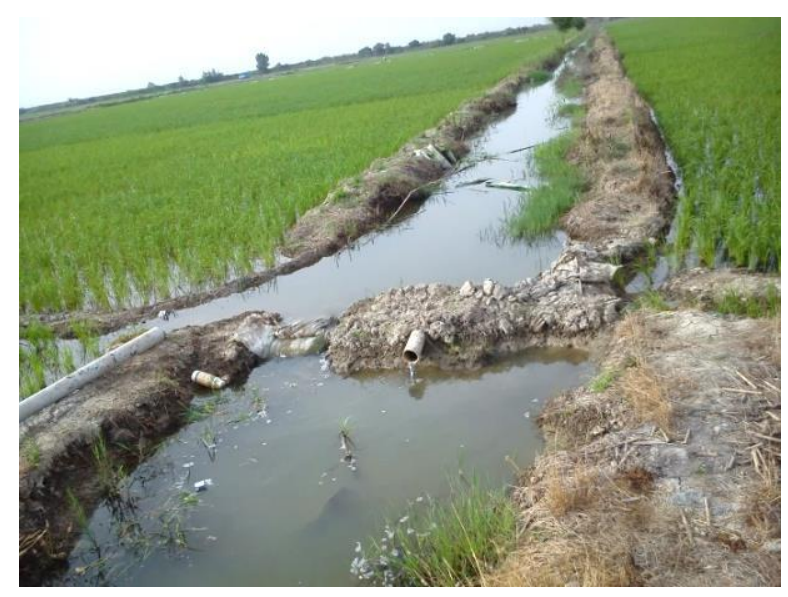

شكل r. ايجاد بند و آبخيرى از زهكش هاى طرح در كرتهاى انتهايى، يروزه تجهيز و نوسازى اراضى اسماعيل كلا، جويبار، مازندران

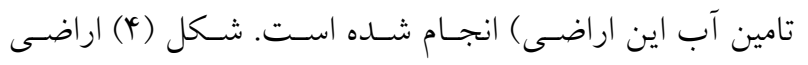

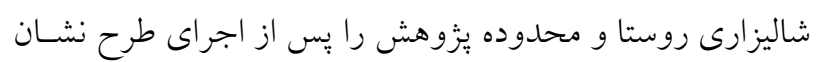
مى دهد. عمليات يوشش بتنى جوىها نيز در بخشى از كانالهـا انجـام

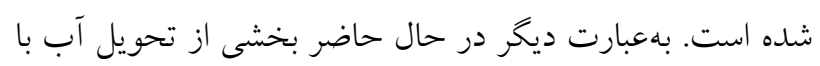

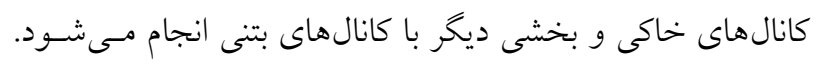

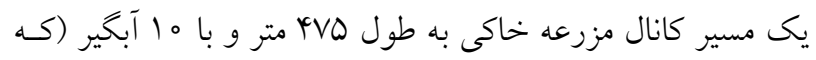

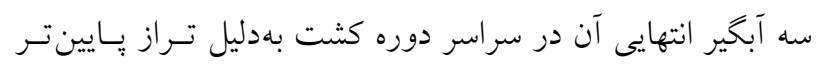

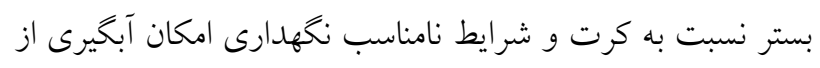

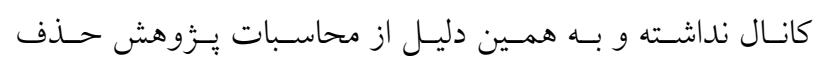

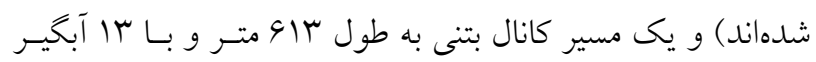

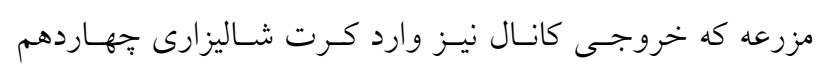

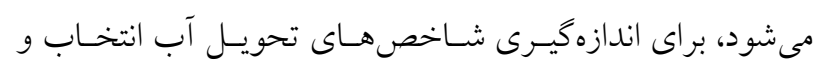

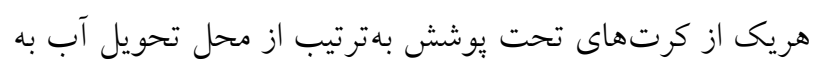

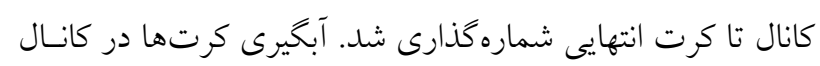

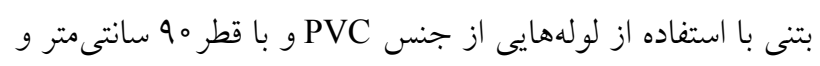

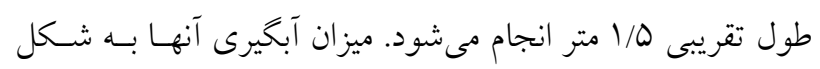
كاملاً سنتى و برحسب تجربيات شخصى توسط خـود كشـاورزان

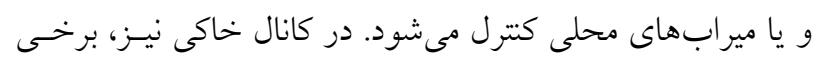

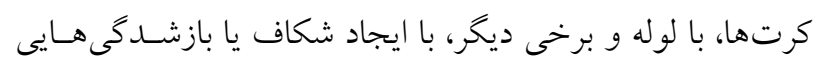
آبخيرى مىشوند كه توسط خود كشاورزان در بشته كانسال ايجـاد

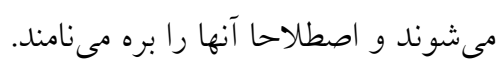

است كه با الكو گرفتن از تحليل هاى اقتصادى و براساس بارامتر

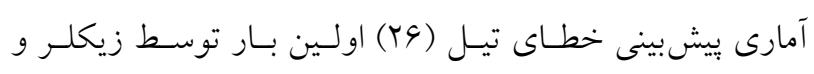

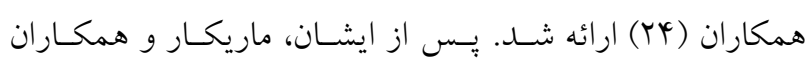

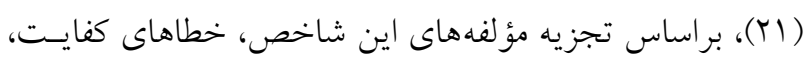

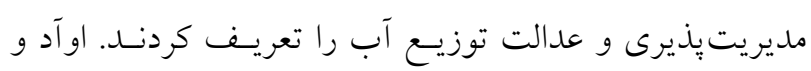

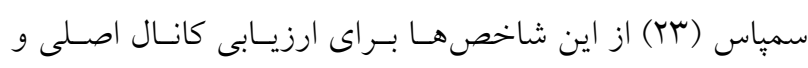

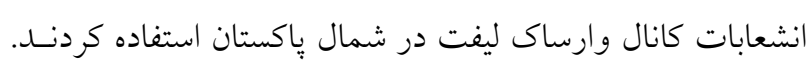

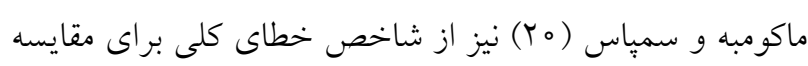

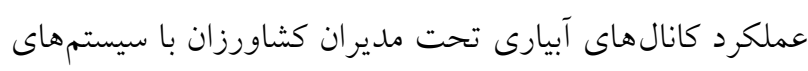
دولتى استفاده كردند.

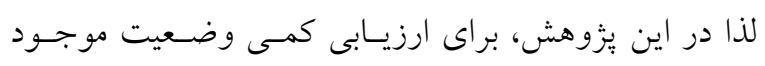

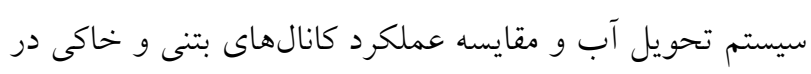

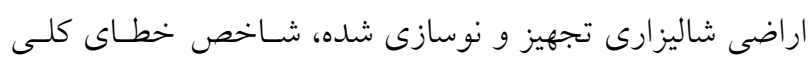

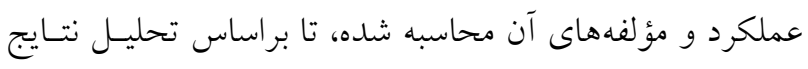

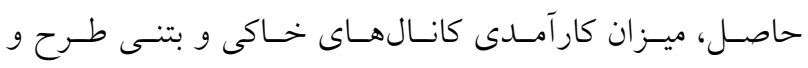
ضرورت اقدامات اصلاحى مورد نياز بعدى مشخص شودان دارسائ

\section{مواد و روشها - - ماد}

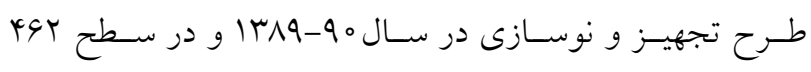

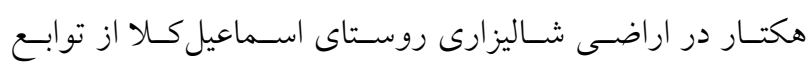

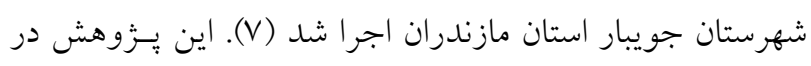

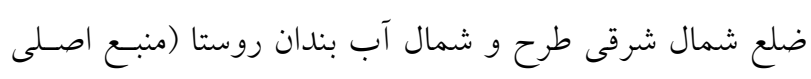




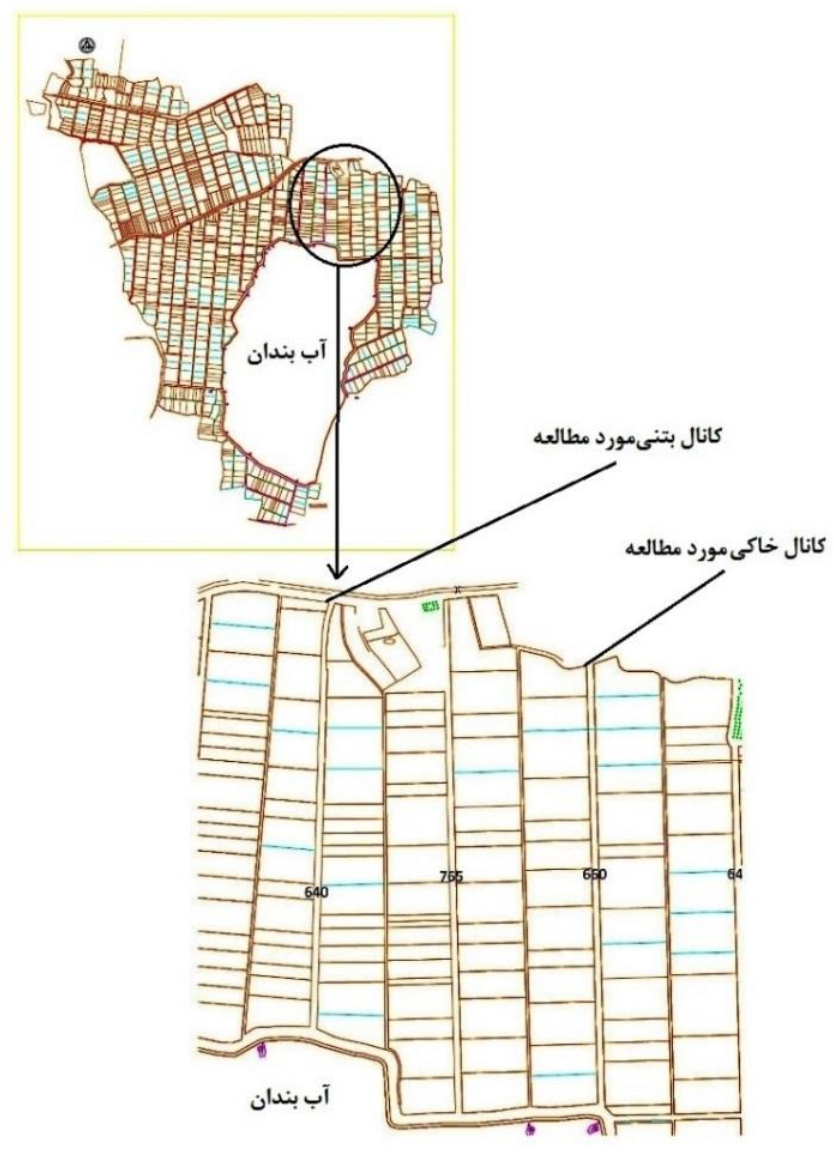

شكل F. مسير كانال هاى مورد مطالعه در طرح تجهيز و نوسازى اراضى شاليزارى روستاى اسماعيل كلا

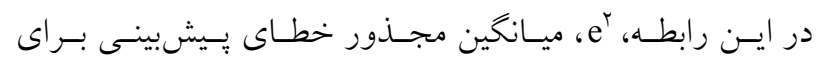

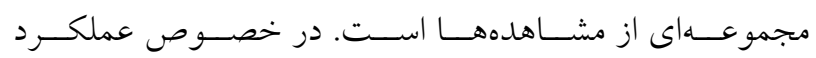

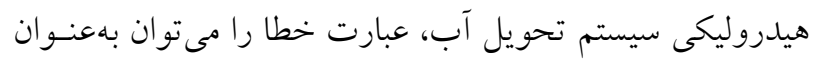

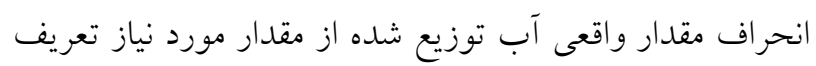

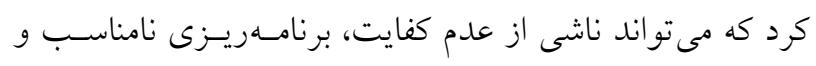

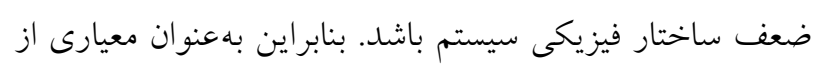

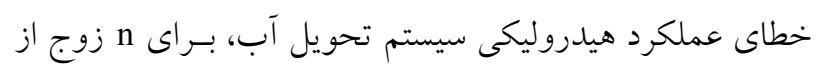

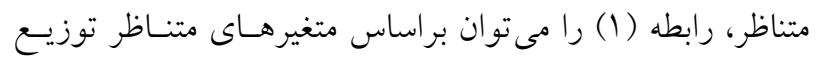

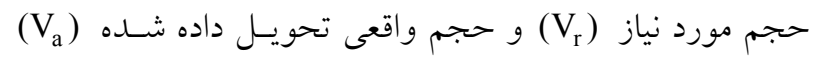
را به اين صورت بازنويسى كرد: $\mathrm{e}^{r}=\frac{1}{\mathrm{n}} \sum_{\mathrm{i}=1}^{\mathrm{n}}\left(\mathrm{P}_{\mathrm{i}}-\mathrm{A}_{\mathrm{i}}\right)^{r}=\frac{1}{\mathrm{n}} \sum_{\mathrm{i}=1}^{\mathrm{n}}\left(\mathrm{V}_{\mathrm{r}_{\mathrm{i}}}-\mathrm{V}_{\mathrm{a}_{\mathrm{i}}}\right)^{r}$ زمانى كه حجم واقعى تحويل داده شده (V) با مقدار مورد

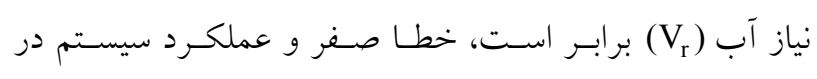

علاوهبر آبخيرها، سازه احسداثى مهـم ديخــى كـه در مسـير

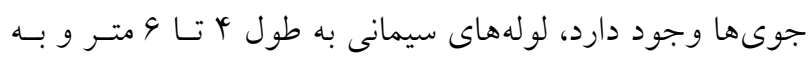

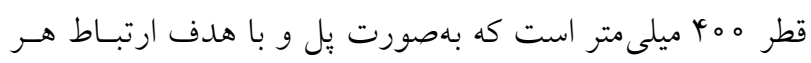

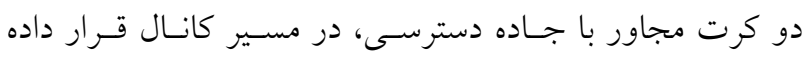
مىشوند. مسيرشماتيك، انواع روش هاى آبخيرى و سازههاى زيرگــــر كانال هاى مورد مطالعه، در شكل (ه) نشان داده شده است. شاخص هاى ارزيابى عملكرد

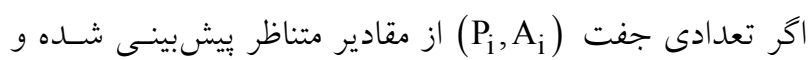

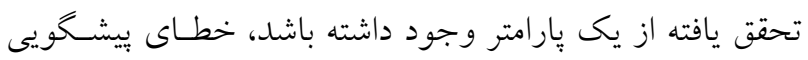

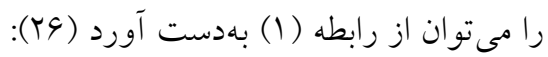
$\mathrm{e}^{r}=\frac{1}{\mathrm{n}} \sum_{\mathrm{i}=1}^{\mathrm{n}}\left(\mathrm{P}_{\mathrm{i}}-\mathrm{A}_{\mathrm{i}}\right)^{r}$ 


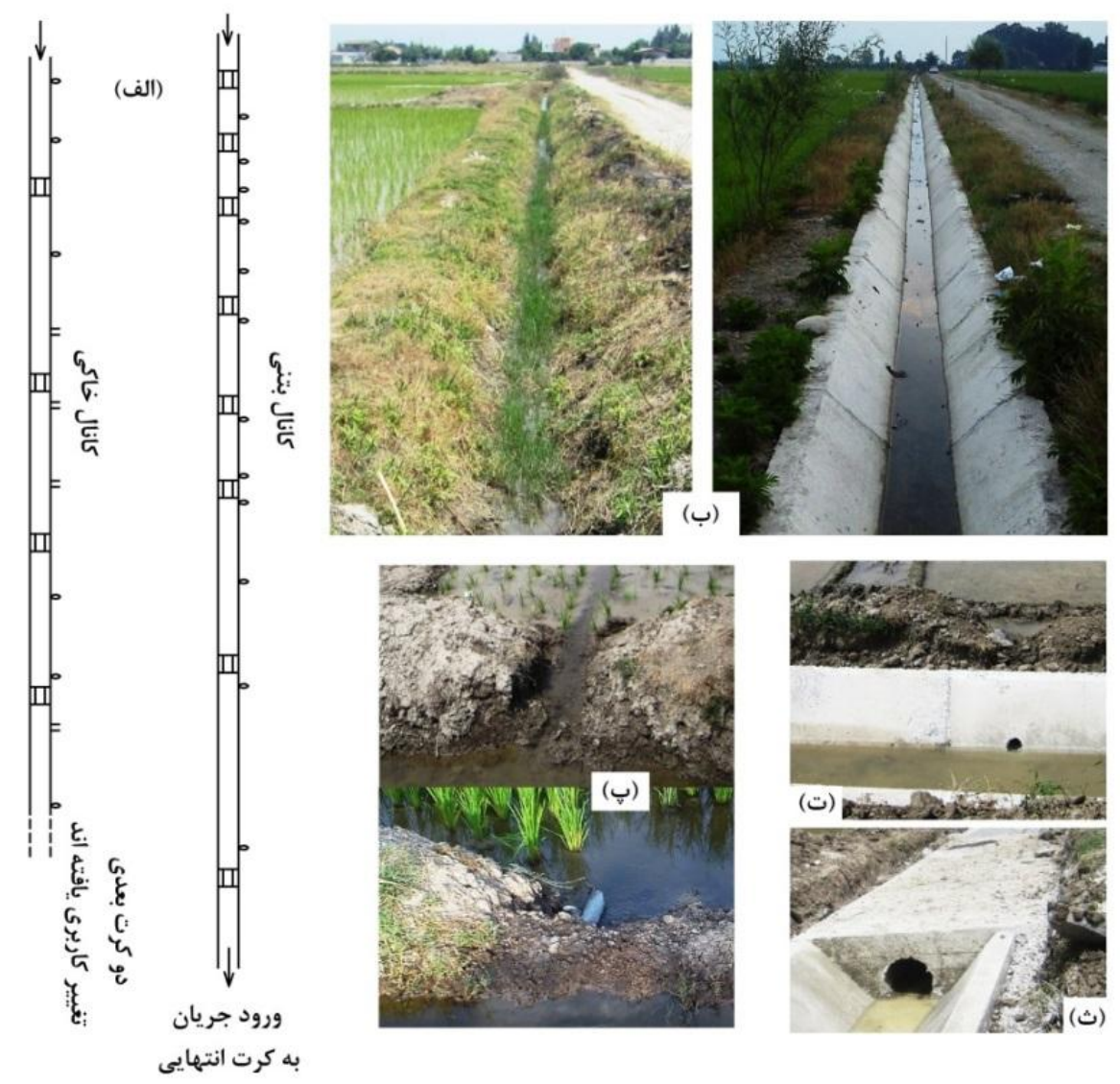

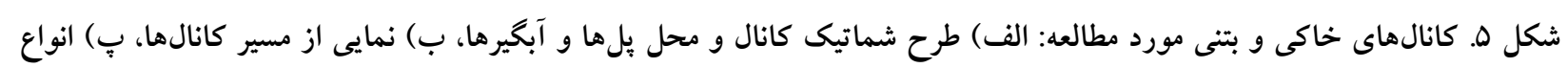

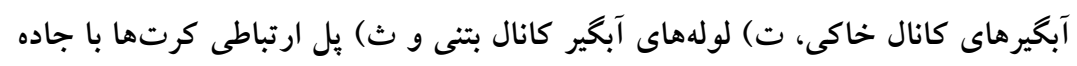

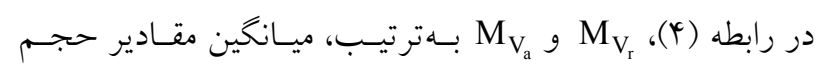

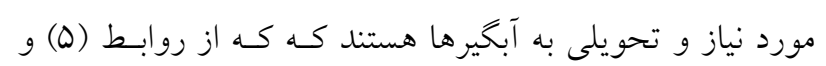

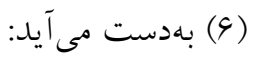

$$
\begin{aligned}
& \mathrm{M}_{\mathrm{V}_{\mathrm{r}}}=\frac{1}{\mathrm{n}} \sum_{\mathrm{i}=1}^{\mathrm{n}}\left(\mathrm{V}_{\mathrm{r}}\right)_{\mathrm{i}} \\
& \mathrm{M}_{\mathrm{V}_{\mathrm{a}}}=\frac{1}{\mathrm{n}} \sum_{\mathrm{i}=1}^{\mathrm{n}}\left(\mathrm{V}_{\mathrm{a}}\right)_{\mathrm{i}}
\end{aligned}
$$

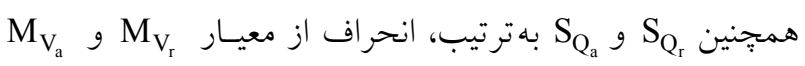

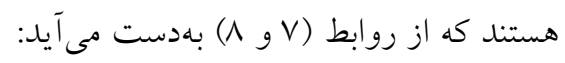$$
\mathrm{S}_{\mathrm{V}_{\mathrm{r}}}=\left[\frac{1}{\mathrm{n}} \sum_{\mathrm{i}=1}^{\mathrm{n}}\left(\mathrm{V}_{\mathrm{r}_{\mathrm{i}}}-\mathrm{M}_{\mathrm{V}_{\mathrm{r}}}\right)^{r}\right]^{\frac{1}{r}}
$$$$
\mathrm{S}_{\mathrm{V}_{\mathrm{a}}}=\left[\frac{1}{\mathrm{n}} \sum_{\mathrm{i}=1}^{\mathrm{n}}\left(\mathrm{V}_{\mathrm{a}_{\mathrm{i}}}-\mathrm{M}_{\mathrm{V}_{\mathrm{a}}}\right)^{\mathrm{r}}\right]^{\frac{1}{r}}
$$

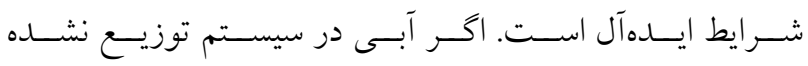
باشد (Va

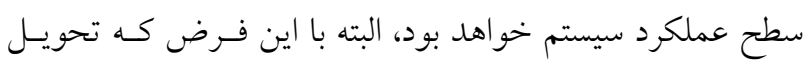

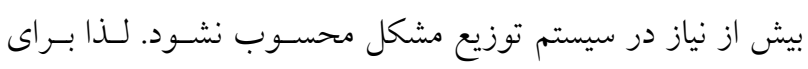

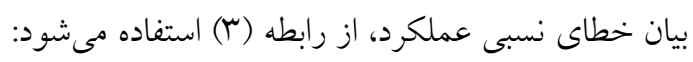
$e_{r}^{r}=\frac{1}{n} \sum_{i=1}^{n} \frac{\left(V_{r_{i}}-V_{a_{i}}\right)^{r}}{V_{r_{i}}^{r}}$

با توجه به اينكه هدف ارزيابى عملكرد بر مبناى كفايت، عدالت

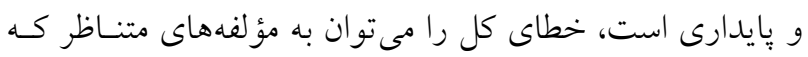
در ادامه آورده شده است، تجزيه كرد: $\frac{1}{\mathrm{n}} \sum_{\mathrm{i}=1}^{\mathrm{n}}\left(\mathrm{V}_{\mathrm{r}_{\mathrm{i}}}-\mathrm{V}_{\mathrm{a}_{\mathrm{i}}}\right)^{r}=\left(\mathrm{M}_{\mathrm{V}_{\mathrm{r}}}-\mathrm{M}_{\mathrm{V}_{\mathrm{a}}}\right)^{r}$ 


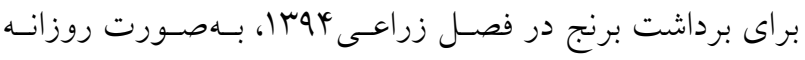

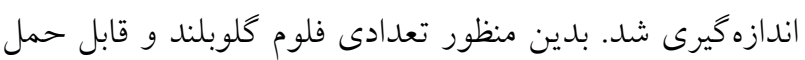
و نقل RBC، براساس ابعاد ارائه شده توسط كلمنس و همكاران

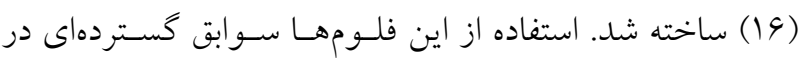

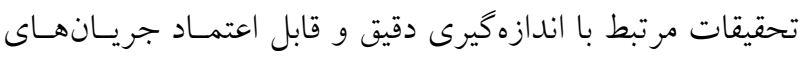

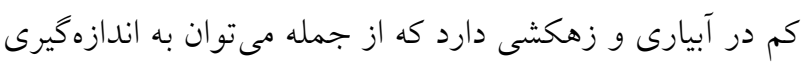

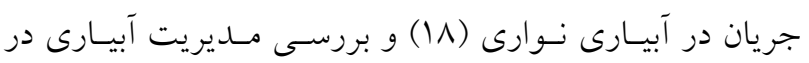
اراضى شاليزارى (TO) اشاره كرد. براساس بيشبينى اوليسه دبسى

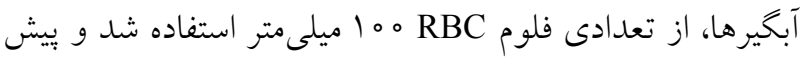

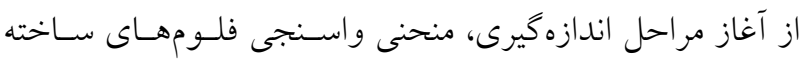

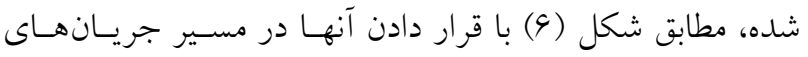

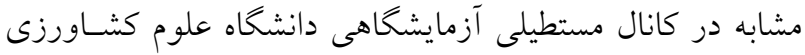
و منابع طبيعى سارى به ابعاد براى كنترل صحت اندازهيرى هــا ( $)$ ( جريان تحويلى به كانالهاى مزرعه با دو دستخاه بارشال فلوم 9 اينج ساخت شركت سيماب الكترونيك به طول 90 اسانتى متر و و

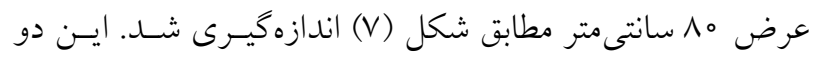

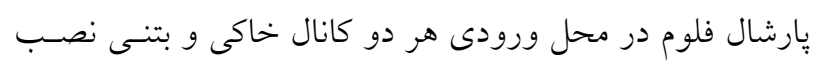
و به روش حجمى، منحنى واسنجى و رابطه دبسى - اشـل ارائسه

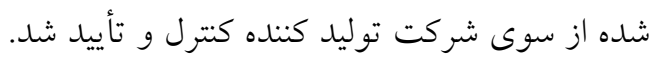

\section{محاسبه دبى موردنياز}

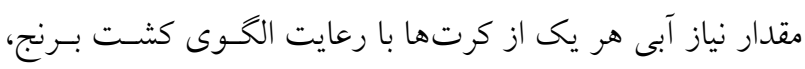
تقويم كشتو كار هر كرت و با فواصـل زمـانى هـ ال روزه از آغـاز

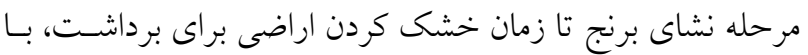

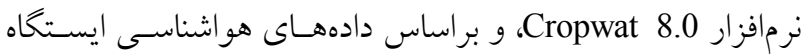

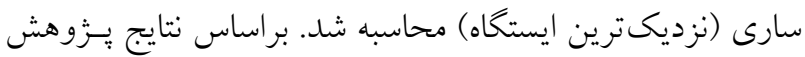

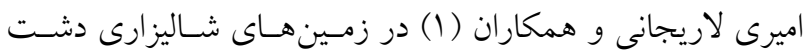
هر از استان مازندران، اختلاف معنىدارى در سطح ينج درصد بين براورد نياز آبى مــل كرايـوات و لايسـيمتر وجـود نـــارد. مقــار

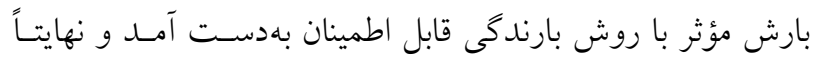

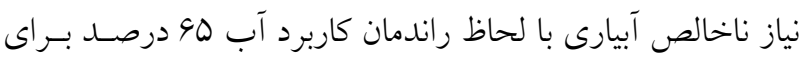

و r هم ضريب همبستخى بين V و V V است كه بـه صـورت رابطه (9) تعريف مى مورد:

$\mathrm{r}=\frac{1}{\mathrm{~S}_{\mathrm{V}_{\mathrm{r}}} \cdot \mathrm{S}_{\mathrm{V}_{\mathrm{a}}}}\left[\frac{1}{\mathrm{n}} \sum_{\mathrm{i}=1}^{\mathrm{n}}\left(\mathrm{V}_{\mathrm{r}_{\mathrm{i}}}-\mathrm{M}_{\mathrm{V}_{\mathrm{r}}}\right)\left(\mathrm{V}_{\mathrm{a}_{\mathrm{i}}}-\mathrm{M}_{\mathrm{V}_{\mathrm{a}}}\right)\right]$

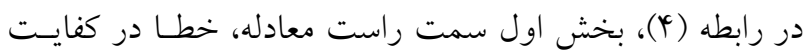

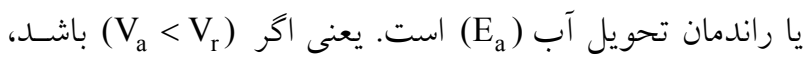

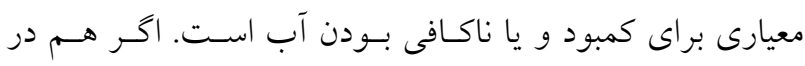

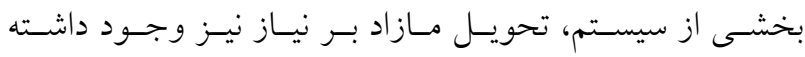
باشد (V)

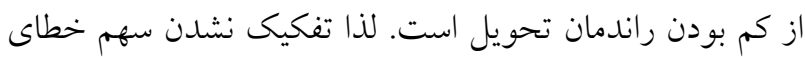

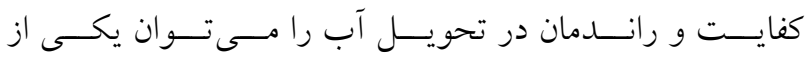
محدوديتهاى اساسى اين روش دانست. بخش دوم كه تفـاوت

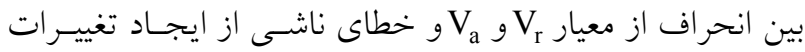
نابرابر در دبى تحويلى نسبت به مـورد نيـاز اسـت را مسىتـوان بهعنوان شاخصى از پايدارى سيستم و خطا در توانايى مديريت

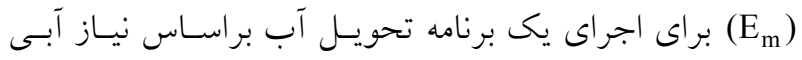

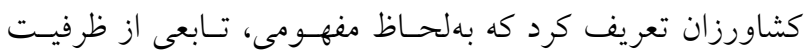

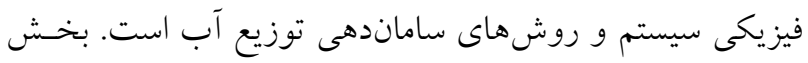

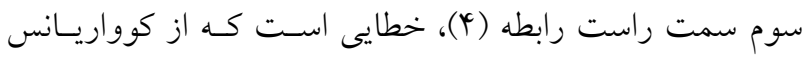

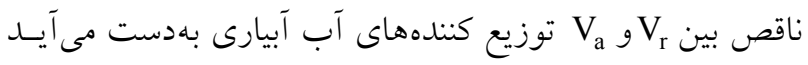

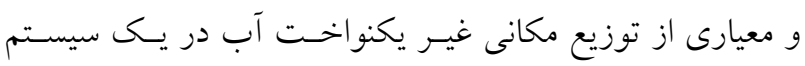

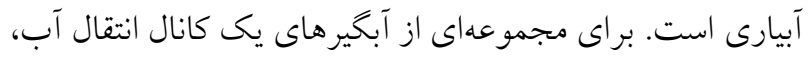

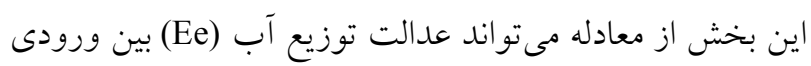

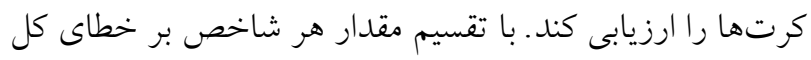

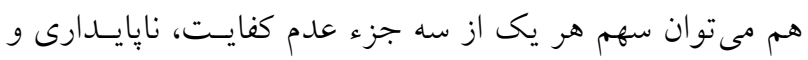
ناعادلانه بودن توزيع رادر خطاى كل (كل سمت راست معت معادله)

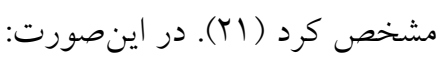

$\mathrm{E}_{\mathrm{a}}+\mathrm{E}_{\mathrm{m}}+\mathrm{E}_{\mathrm{e}}=1$

اندازهيرى جريان تحويلى

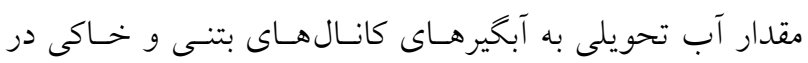

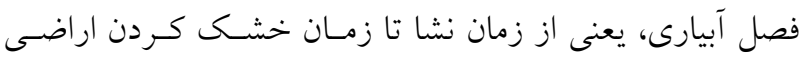




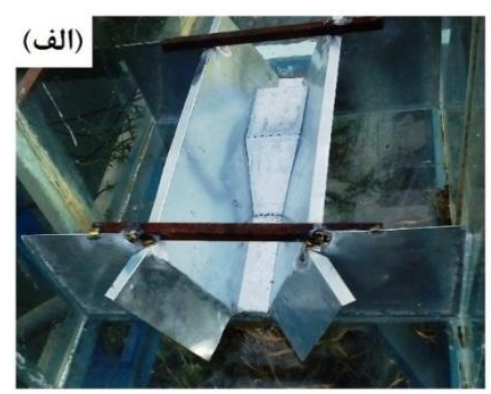

(ب)
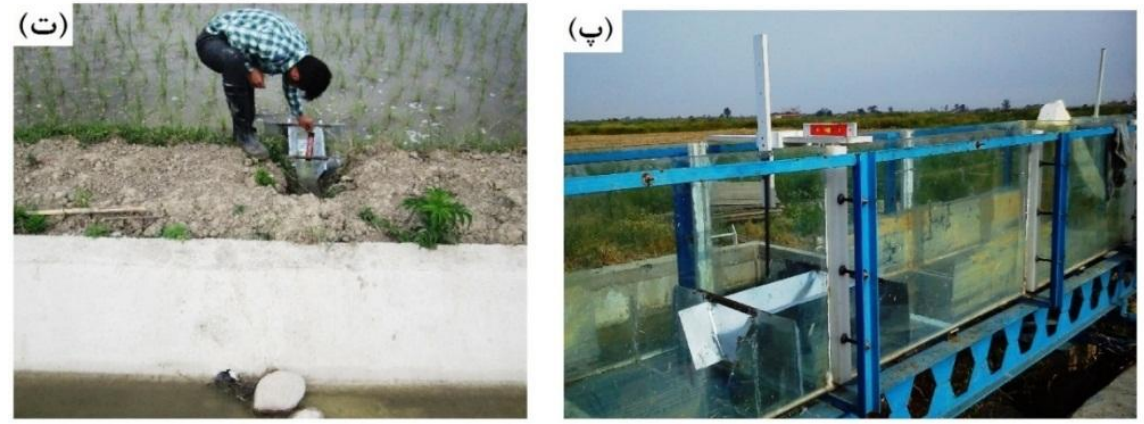

شكل و. فلوم RBC م 1 ميلى مترى: الف) فلوم ساخته شده و مورد استفاده در اين برُوهش، ب) طرح شماتيك و ابعاد فلوم

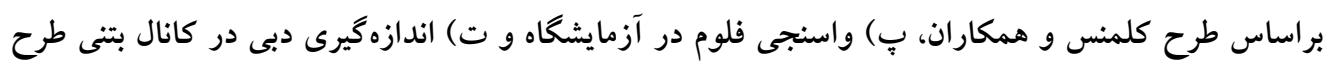

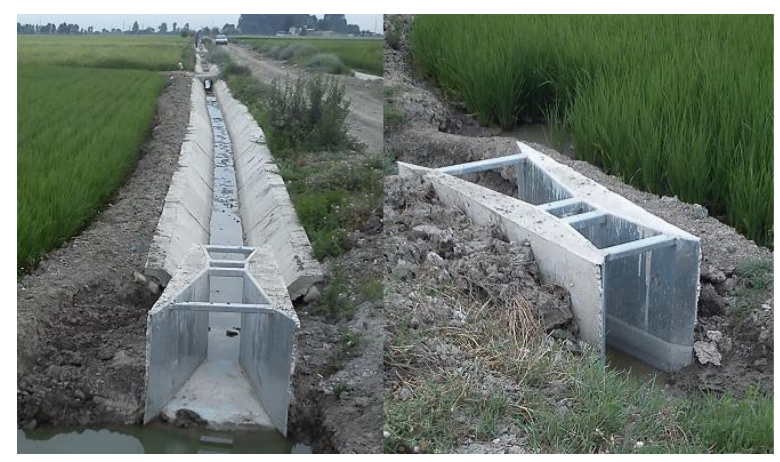

شكل V. نصب بِارشال فلوم در ورودى كانالهاى بتنى و خاكى

با توجه به نتايج اندازهگيرىها و محاسبات انجـام شــه، در

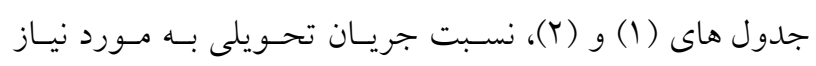

براى هر كرت در دهلهاى مختلـف آبيـارى نشـان داده $\left(\frac{V_{a}}{V_{r}}\right)$

شد.

در جدولهاى (r) و (Y)، نيز نتايج محاسبه شـاخص هـاى

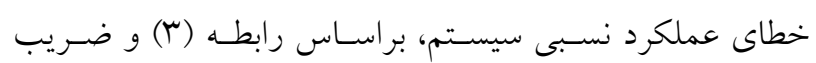

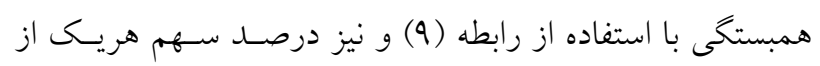

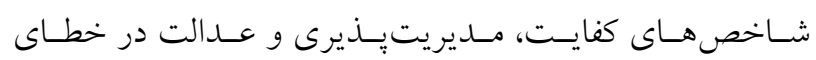

كرتهاى تجهيز و نوسازى شده براساس يزوهشهـاى جلاللى و همكاران (D) و بابايور و همكاران (Y) محاسبه شد.

نتايج با صرفنظر كردن از تلفات انتقال در مسير كانالها و با توجـهـ بــه

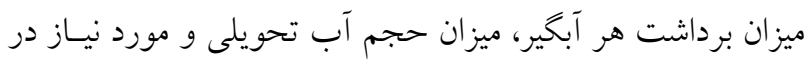

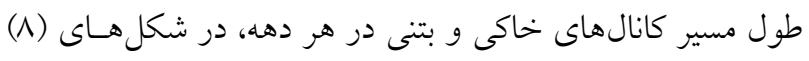

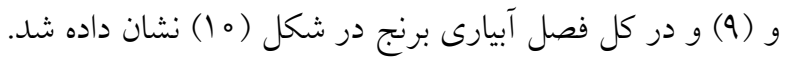



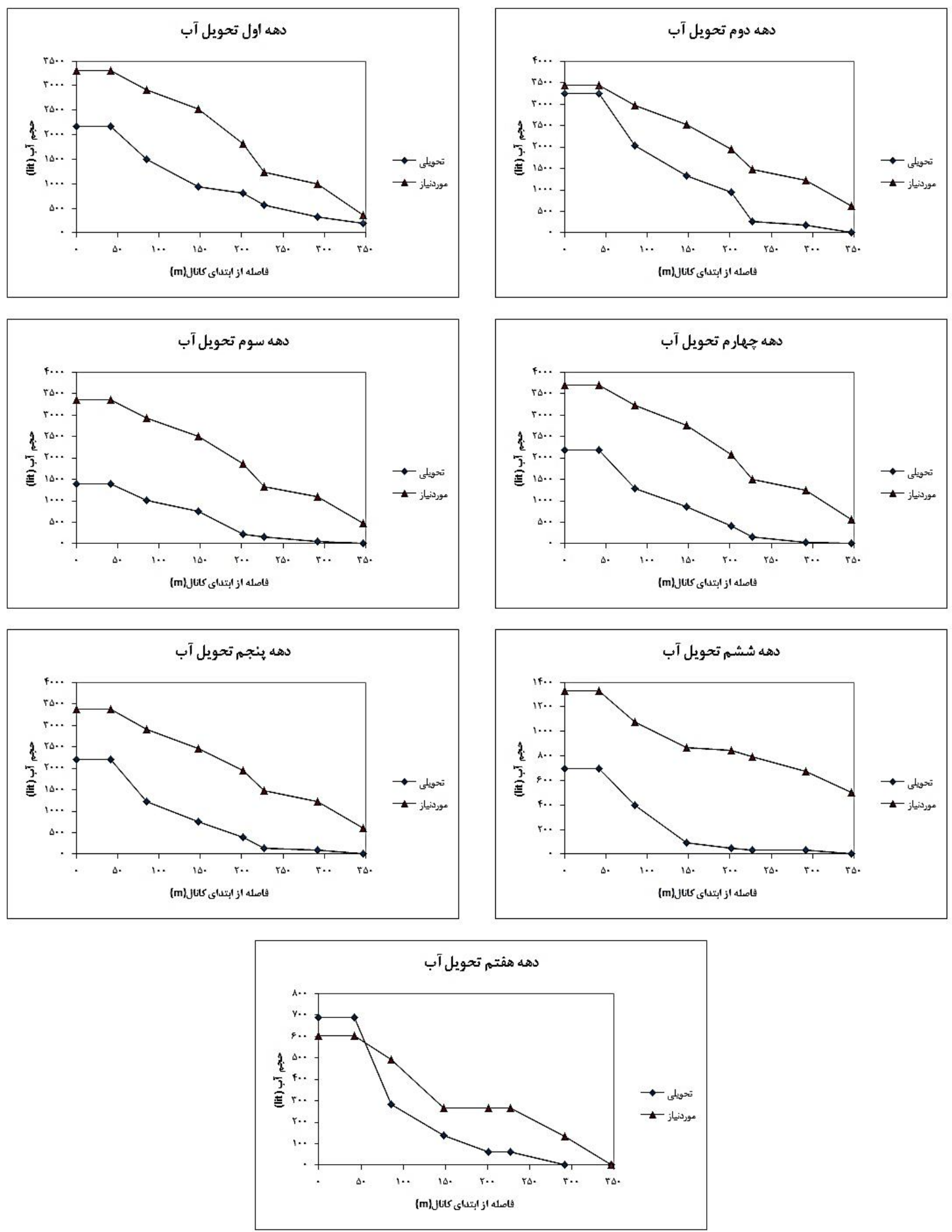

شكل^^. حجم آب تحويلى و مورد نياز كانال خاكى در هر يك از دهدهاى آبيارى 

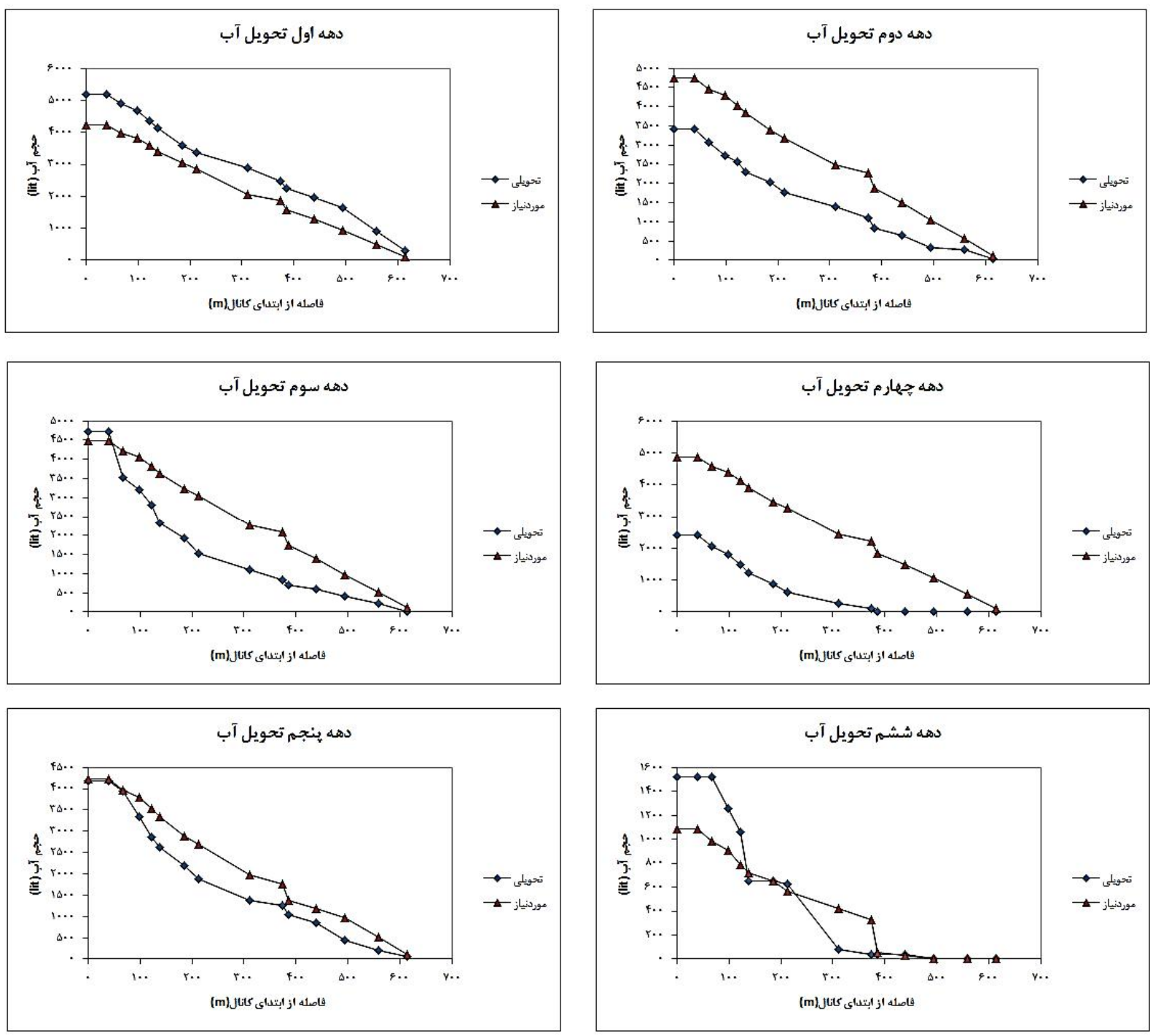

شكل ه. حجم آب تحويلى و مورد نياز كانال بتنى در هر يك از دهدهاى آبيارى
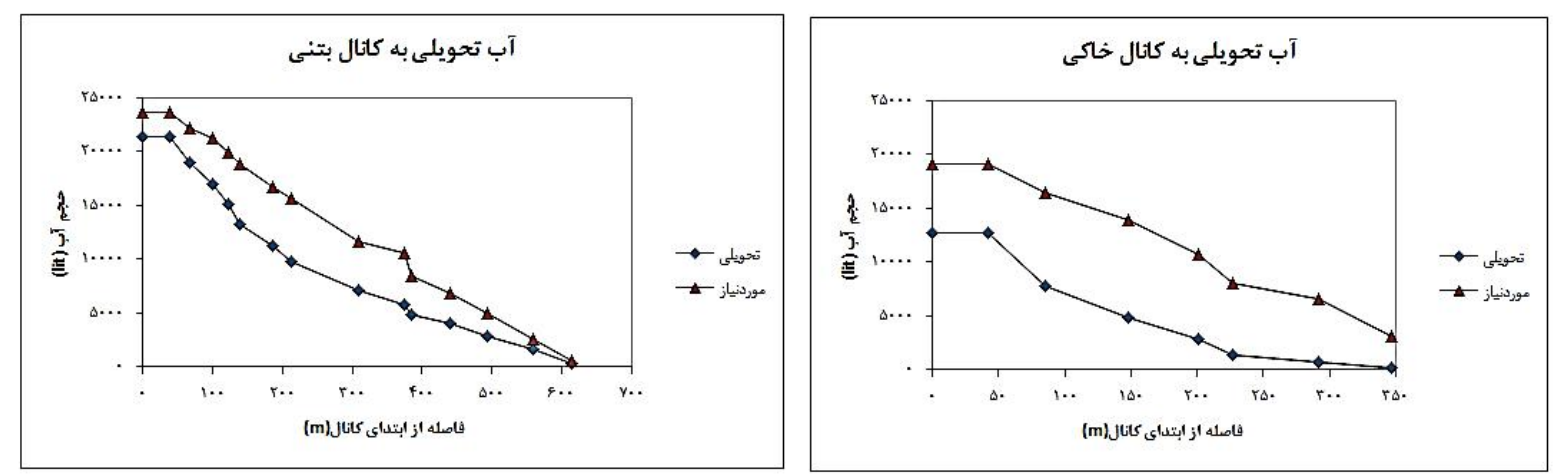

شكل ه ا. كل حجم آب تحويلى و مورد نياز كانالهاى خاكى و بتنى مورد مطالعه 
جدول ا. نسبت دبى تحويلى به دبى مورد نياز در كانال خاكى

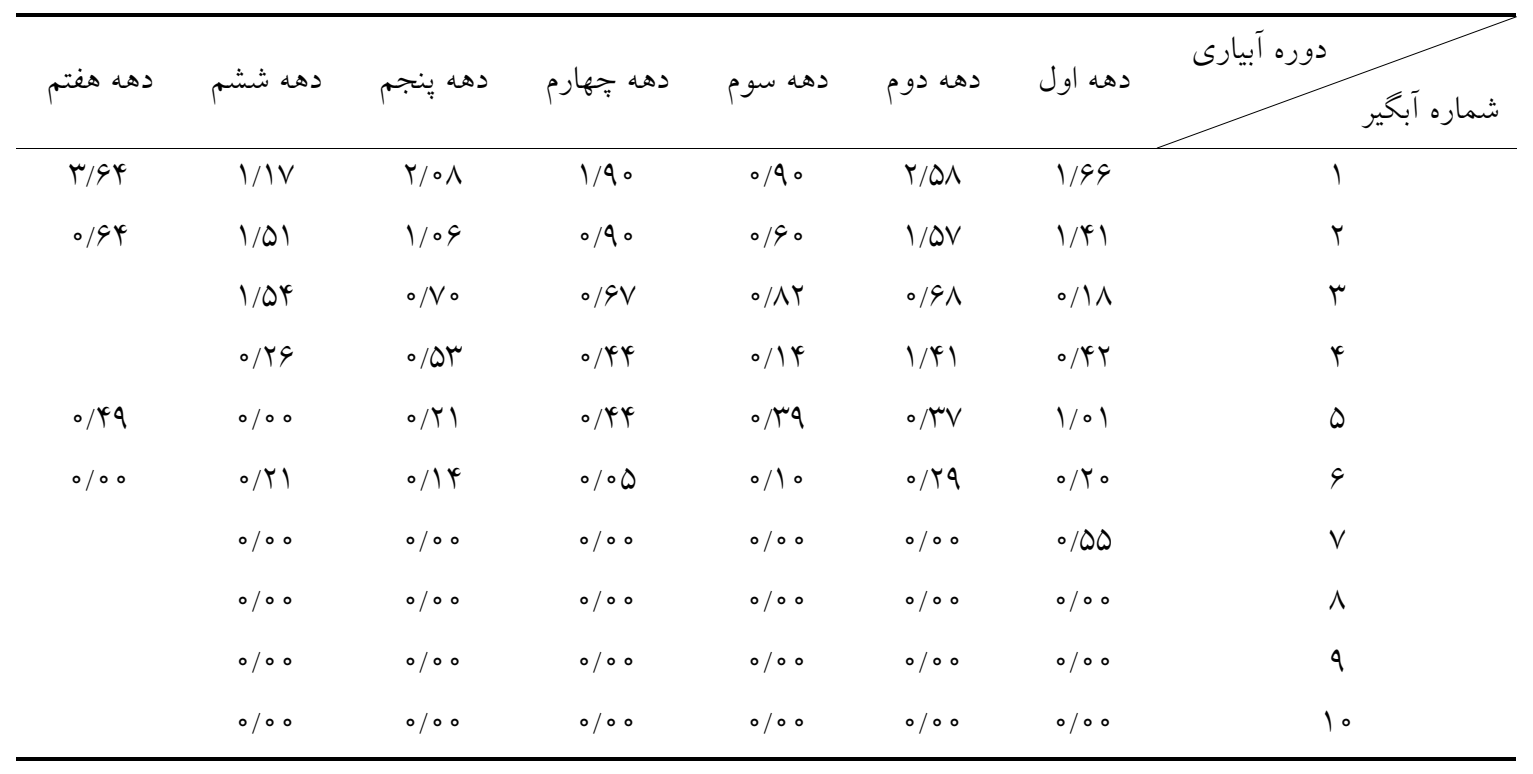

جدول Y. نسبت دبى تحويلى به دبى مورد نياز در كانال بتنى

\begin{tabular}{|c|c|c|c|c|c|c|}
\hline دهه ششم & دهل ينجم & دهه جهارم & دهـ سوم & دهل دوم & دهه اول & \\
\hline & $\circ / \wedge \mathrm{V}$ & $1 / 19$ & $\varphi / 4 V$ & $1 / \pi \circ$ & $1 / 0 r$ & 1 \\
\hline G/T & $r / D 1$ & $1 / Y \wedge$ & $r / O \circ$ & $1 / M$ & $1 / 49$ & $r$ \\
\hline $1 / 9 \mathrm{~V}$ & $1 / \wedge \Delta$ & $1 / r 1$ & $1 / 09$ & $0 / 91$ & $1 / \pi y$ & $r$ \\
\hline \multirow[t]{2}{*}{$0 / 9 \circ$} & $1 / T V$ & س 1/א & $T / \Delta Q$ & $1 / 4 \circ$ & $1 / 49$ & 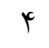 \\
\hline &.$/ 90$ & $\circ / V Y$ & $1 / 04$ & .09 & $1 / 0 \circ$ & 0 \\
\hline ORY & $1 / 4 \wedge$ & $1 / 1 V$ & $r / Y^{4}$ & $1 / \pi r$ & $1 / T r$ & 9 \\
\hline$r / 99$ & $\circ / V I$ & $0 /$ Tr & $\circ / D Y$ & $\circ / 00$ & $0 / 91$ & V \\
\hline $0 / 49$ & $\circ / \Delta \Delta$ & $0 / 91$ & $1 / T V$ & $1 / 49$ & $r / 19$ & $\wedge$ \\
\hline$\% / 00$ & $\circ / \Delta Y$ & $0 / N$ & $\circ / \mu \wedge$ &.$/ 90$ &.$/ 9 \Lambda$ & 9 \\
\hline$\circ / 0 \circ$ & $1 / 10$ & $\% \circ \circ$ & $\circ / \Gamma \wedge$ & - $/ \Delta T$ & $1 / 09$ & 10 \\
\hline \multirow[t]{4}{*}{$1 / r Y$} & $1 / \Lambda 4$ & $\% \circ 0$ & $0 / 4 y$ & $\circ / V Q$ & $0 / 94$ & 11 \\
\hline & $\circ / \Delta \circ$ & \%०。 & $O / K Y$ & $\circ / \circ \mathrm{V}$ & $1 / 91$ & IT \\
\hline & $\circ / 4 \circ$ & $\%$ &.$/ 09$ & $\circ / \mathrm{OV}$ & $1 / 0 V$ & س \\
\hline & $\circ / 4 \wedge$ & $\%$ & \%०。 & $0 / T G$ & T/AV & 14 \\
\hline
\end{tabular}

عملكرد هر يك از كانالهاى خاكى و بتنى، با استفاده از روابـط شاخص خطاى ناشى از كفايت تحويل، صرفاً مربوط به كمبـود

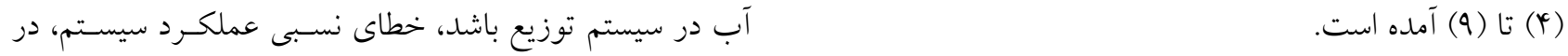
اكر براساس فرضسيات ماريكـار و همكـاران (آY)، تحويـل كانالهاى خاكى و بتنى بهشرح جدول (ه) خواهد بود. اخـتلاف

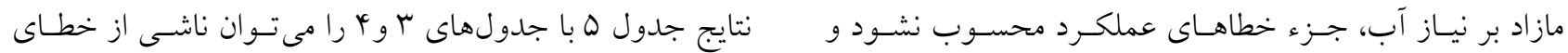


جدول r. شاخصهاى خطاى عملكرد سيستم تحويل آب در كانال خاكى مورد مطالعه

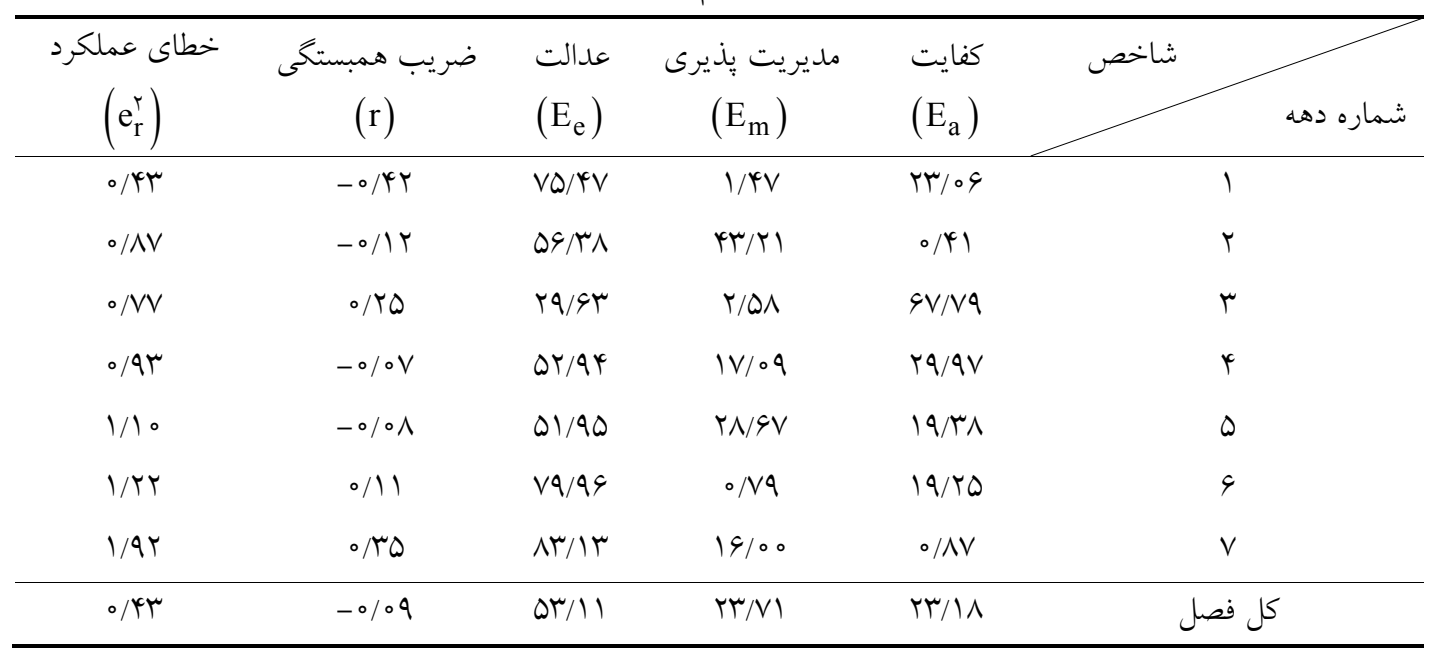

جدول f. شاخصهاى خطاى عملكرد سيستم تحويل آب در كانال بتنى مورد مطالعه

\begin{tabular}{|c|c|c|c|c|c|}
\hline $\begin{array}{c}\text { خطاى عملكرد } \\
\left(e_{r}^{r}\right)\end{array}$ & ضريب همبستى & $\begin{array}{l}\text { عدالت } \\
\left(E_{e}\right)\end{array}$ & $\begin{array}{c}\text { مديريت يذيرى } \\
\left(E_{m}\right)\end{array}$ & $\begin{array}{l}\text { كفايت } \\
\left(E_{a}\right)\end{array}$ & شماره دهـ \\
\hline $0 / Y V$ &.$/ 0 \Lambda$ & $\Lambda T / T V$ & $\circ / N$ & $1 \mathrm{~V} / 00$ & 1 \\
\hline $0 / T V$ & M/Y & $G V / T V$ & $\Lambda / \Delta \Delta$ & $r Y / \circ \Lambda$ & r \\
\hline $1 / 4 y$ & $0 / M Y$ & $\Lambda Y / T Y$ & $10 / 4 T$ & $\circ / \mu Y$ & r \\
\hline $0 / 40$ &.$/ 11$ & $\Delta N / I M$ & $1 / 79$ & $\varphi \circ / \Delta \Lambda$ & r \\
\hline $0 / 91$ & $0 / \mu$ & $99 / 94$ & $0 / 0 Y$ & $0 / 09$ & 0 \\
\hline س & $0 / T r$ & $91 / 11$ & $\mu \Delta / \varphi \Lambda$ & $r / r l$ & 4 \\
\hline $0 / Y \Lambda$ & OKY & $9 \circ / 01$ & $0 / 9 Y^{r}$ & $r / 9 \Lambda$ & كل فصل \\
\hline
\end{tabular}

جدول ه. شاخصهاى خطاى نسبى عملكرد تحويل آب با فرضيات

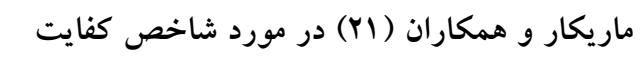

\begin{tabular}{|c|c|c|}
\hline كانال خاكى & كانال بتنى & شماره دهد \\
\hline . MQ & $0 / 04$ & 1 \\
\hline$\circ / 0 \circ$ & $\circ / \Lambda$ & r \\
\hline$\circ / V V$ & $0 / T_{1}$ & $r$ \\
\hline •/A & o/kr & $r$ \\
\hline $0 / 99$ & $\circ / 10$ & 0 \\
\hline $1 / 10$ & 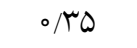 & 9 \\
\hline $1 / 00$ & - & V \\
\hline OMT & $0 / 09$ & كل فصل \\
\hline
\end{tabular}


مشابهت دارد. پايين بودن شـاخص هـاى كفايست و وِايـدارى را

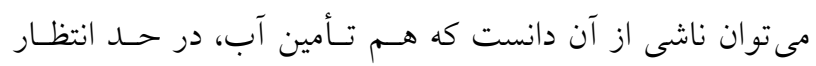

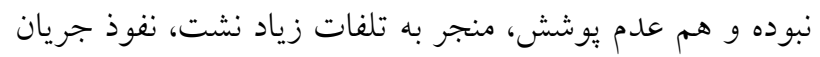

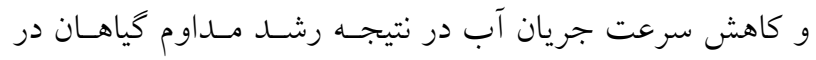

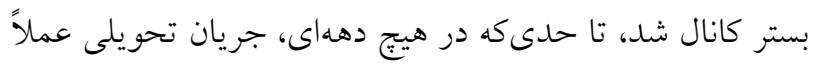

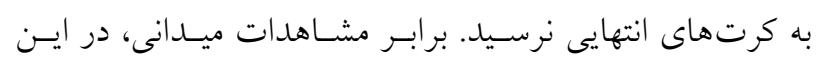

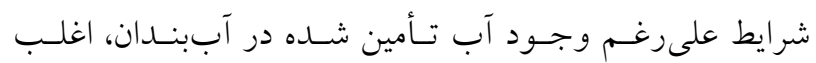

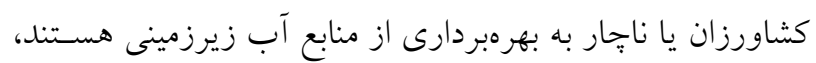

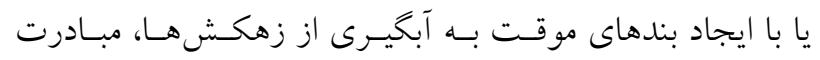

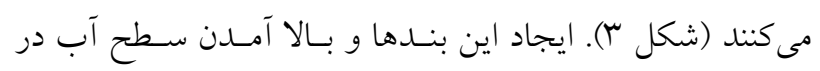

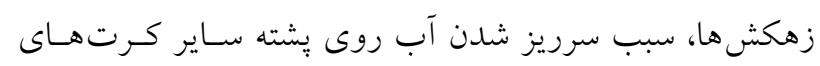

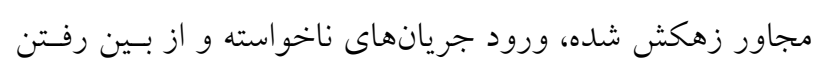

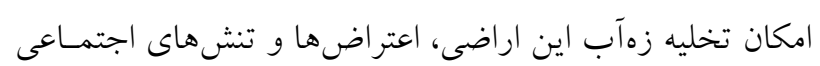
بين كشاورزان را در يى دارد.

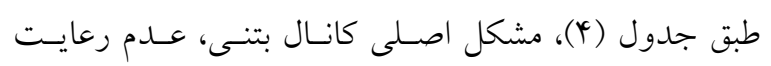

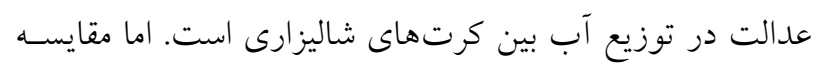

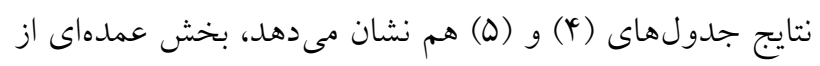

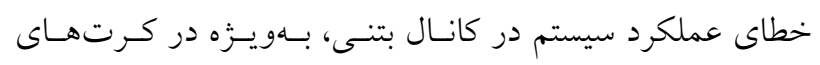

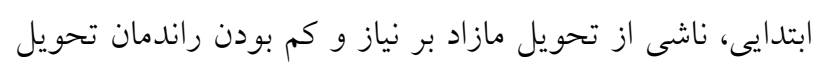

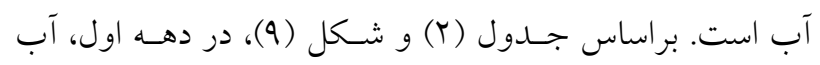

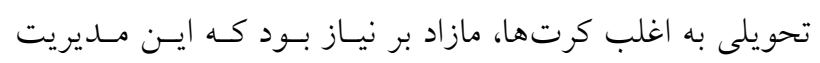

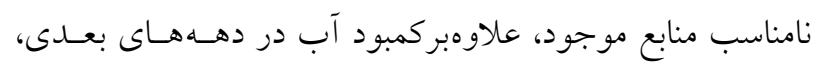

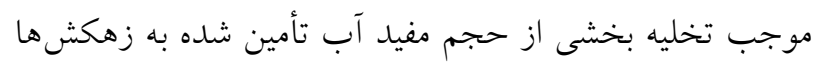

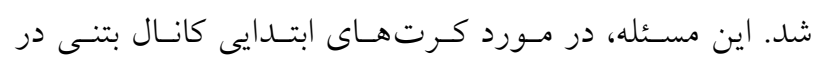

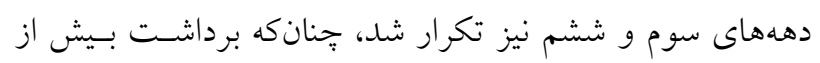

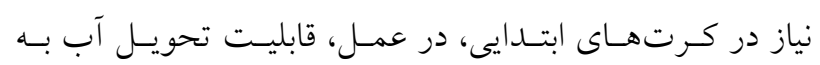

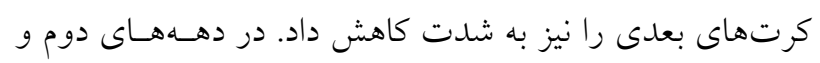

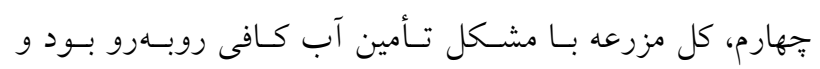

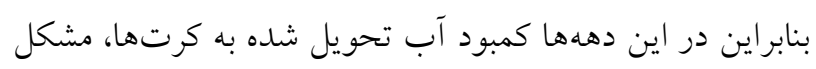

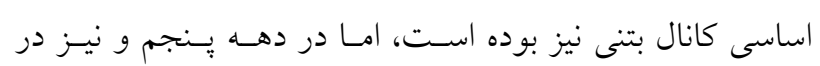

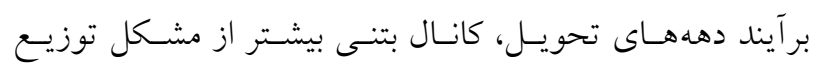

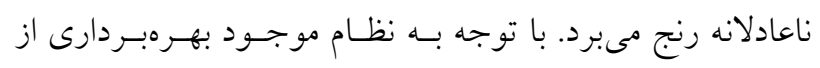

تحويل مازاد بر نياز (راندمان) دانست.

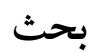

نتايج بررسى خطاى عملكرد سيستم تحويل آب در كانـالهـاى

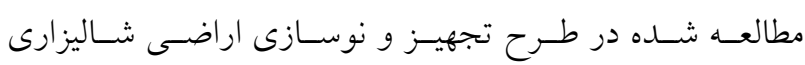

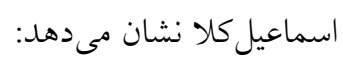
شاخص كلى خطا، در هر دو كانال خاكى و بتنى، در مقايسه با كانالهاى مطالعه شده در بررسى هـاى ماريكـار و همكـار دران

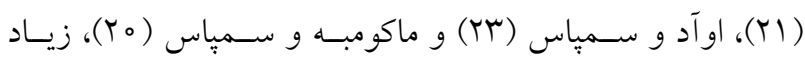

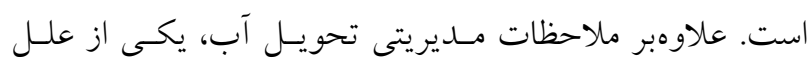

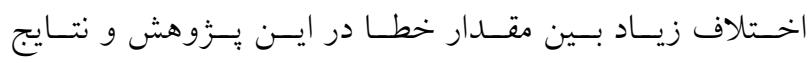

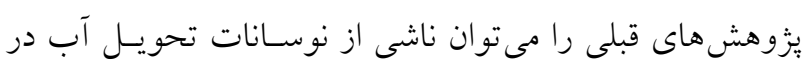

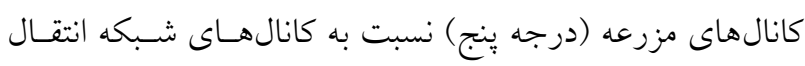

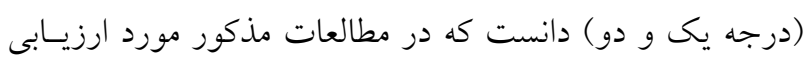

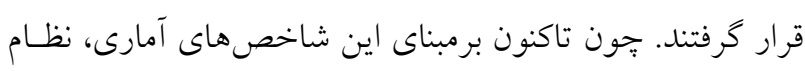

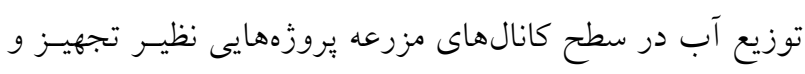

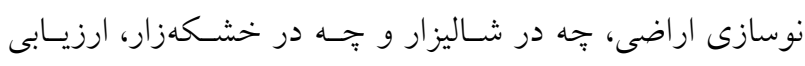
نشده است، لذا نتايج اين يزوهش، قابل درئ مقايسه كمى با مطالعات

$$
\text { قبلى در شرايط مشابه نيست. }
$$

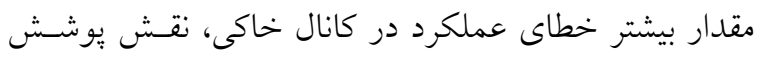

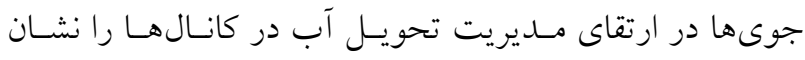

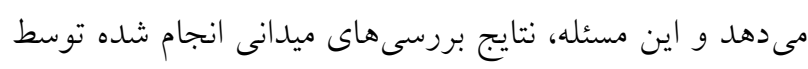

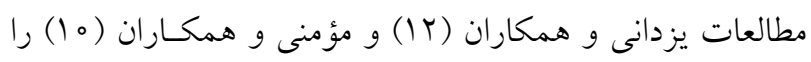

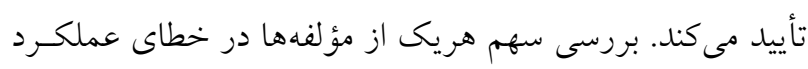
مطابق جدول (r) نشان مى دهد، بهجز دهه اول كه امكان تـأمين

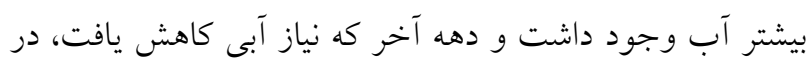

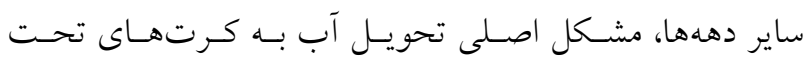

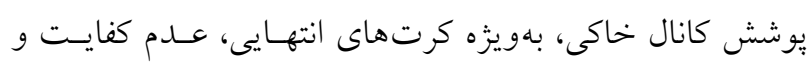

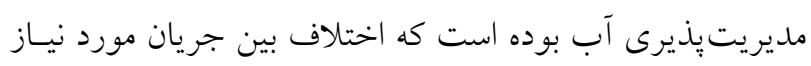
و تحويلى در جدول (1) و شكل (1) نيـز ايسن نتيجـهـ را تأييـا

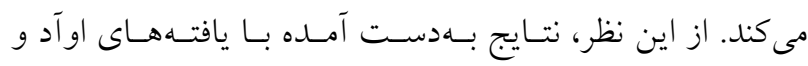

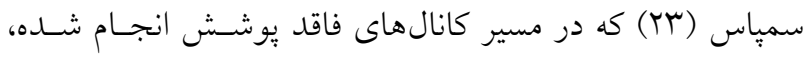


تغيير رقوم بستر كانال نسبت به كرت در طى زمان و شرايط

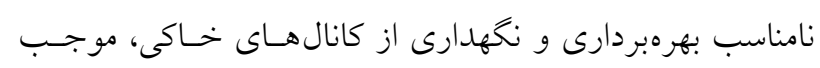

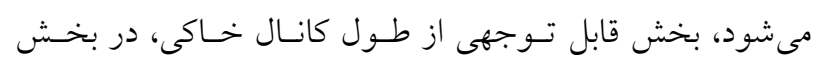

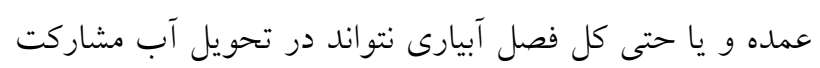

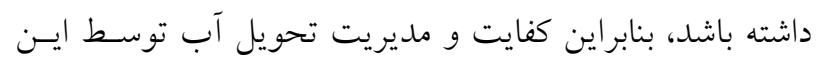

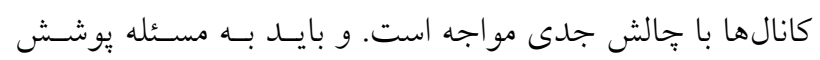

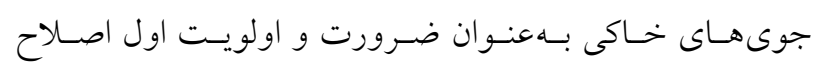

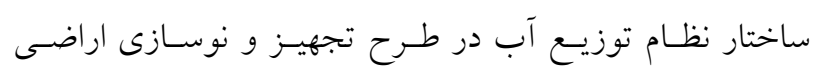
شاليزارى توجه شود.

با بررسى شاخصهاى خطاى عملكرد تحويل آب در كانـال

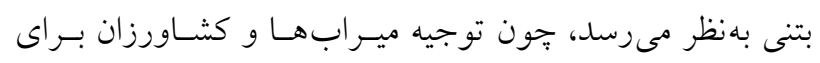

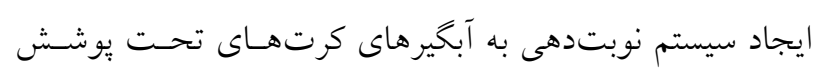

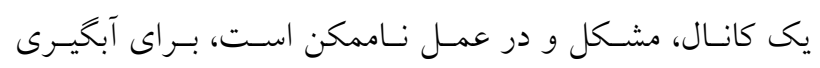

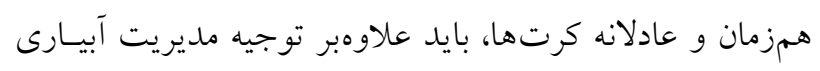

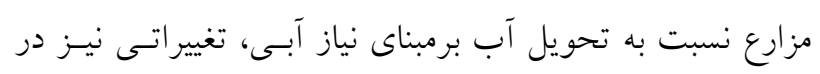

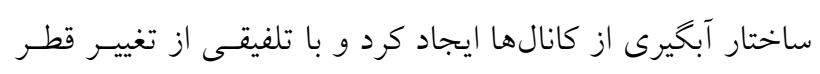

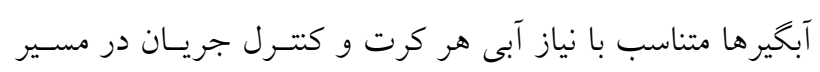

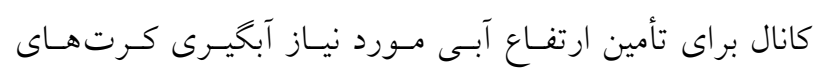

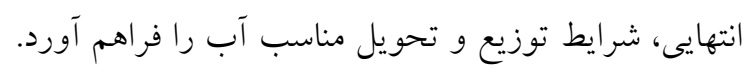

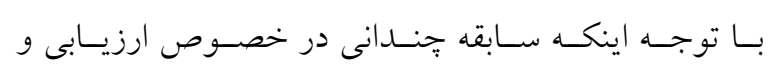

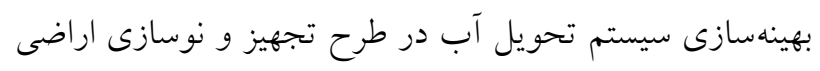

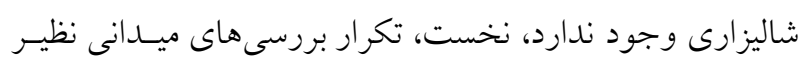

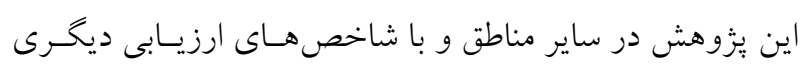

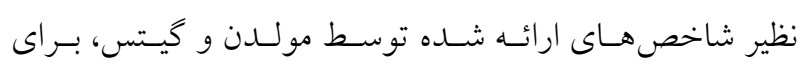
يزوهش هاى آينده بيشنهاد مى شود و دوم براى يافتن مدلى بهينه

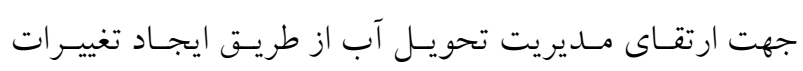

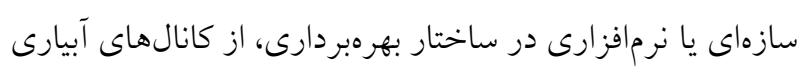

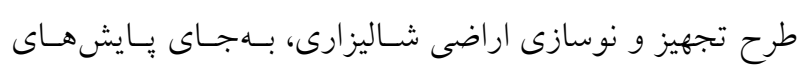

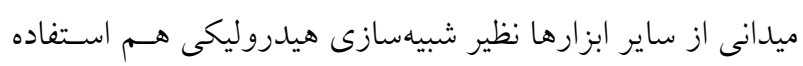
شده و نتايج با دادههاى ميدانى مقايسه شود.
طرح، منشأ اين مشكل را مىتوان عـلاوهبـر سـاختار تجربسى و

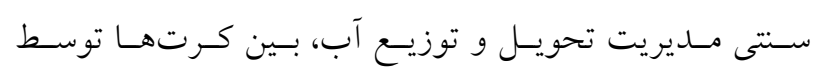

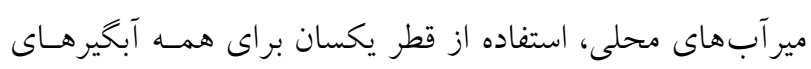

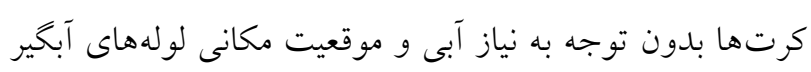
در طول كانال و فقدان سازههاى كتترل در مسير جريان دانست.

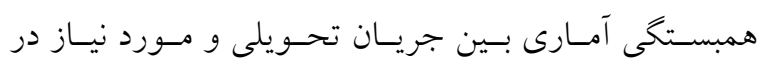

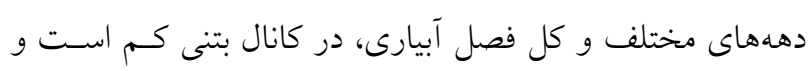

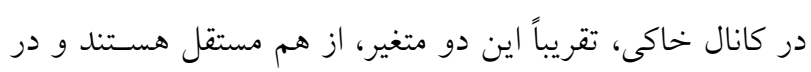

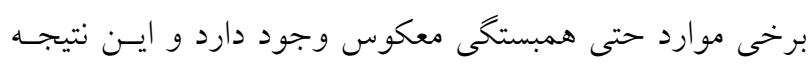

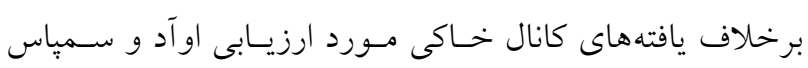

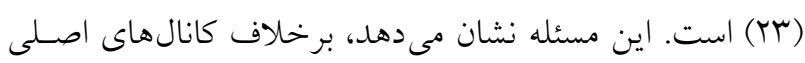

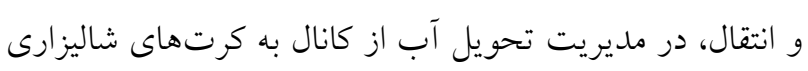

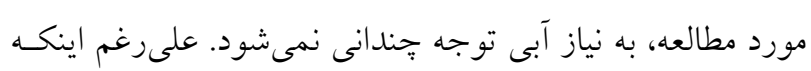

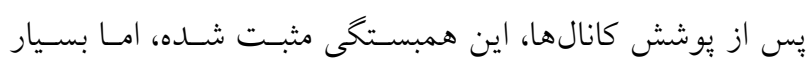

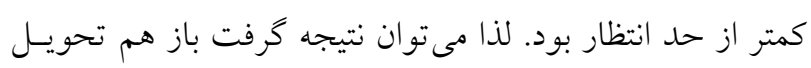

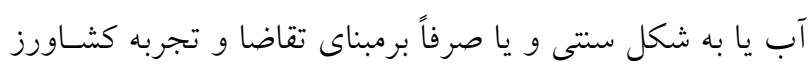

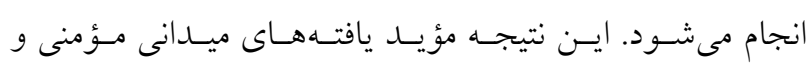

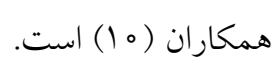

\section{نتيجه گيرى}

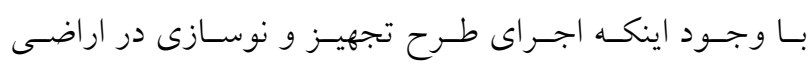

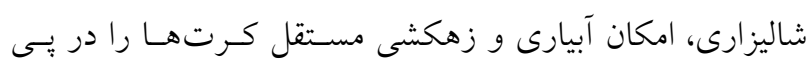

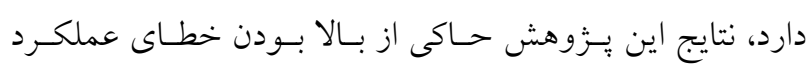

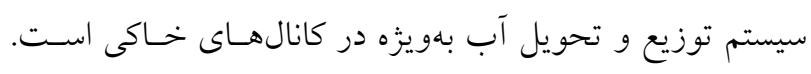

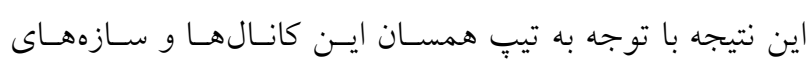

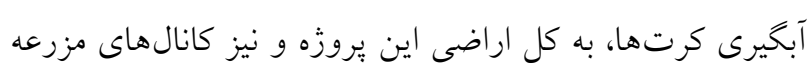

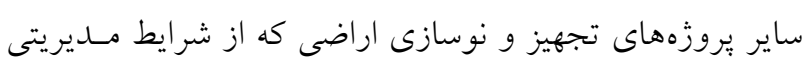

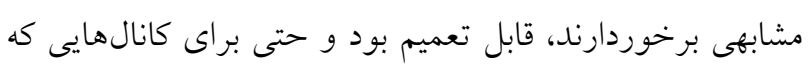

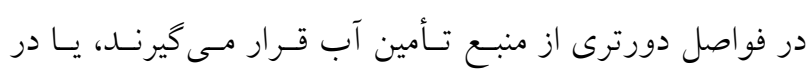

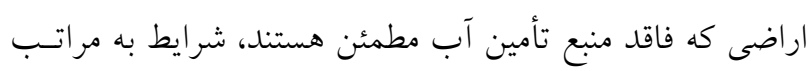


منابع مورد استفاده

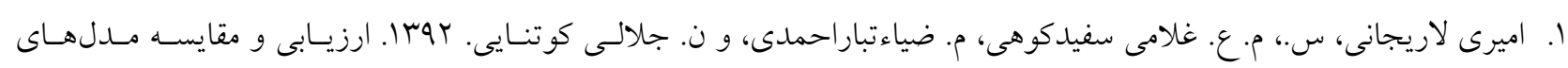
NETWAT و CROPWAT

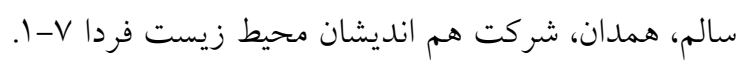

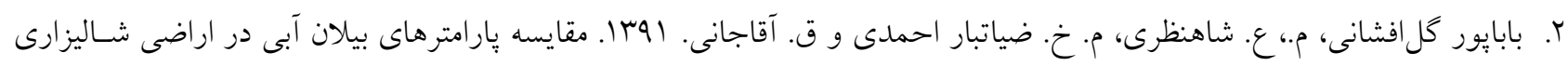

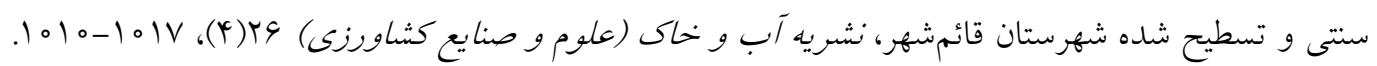

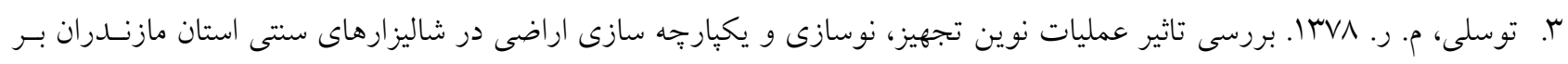

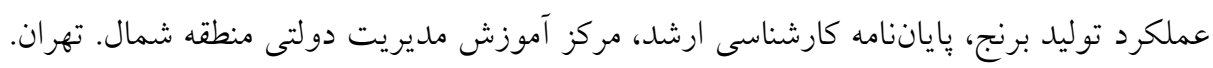

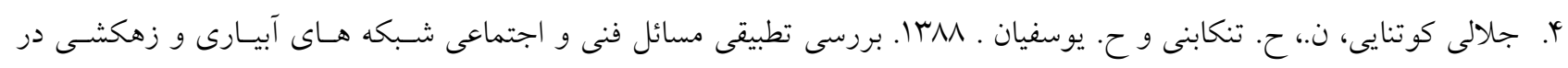

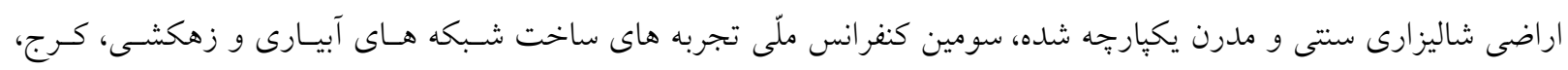

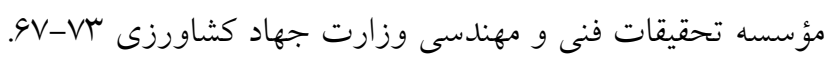

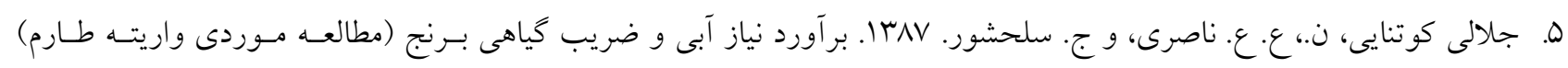

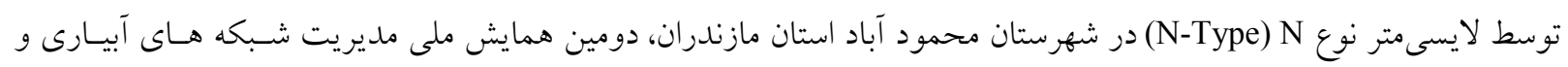

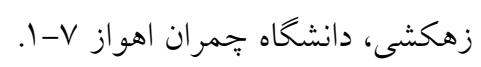

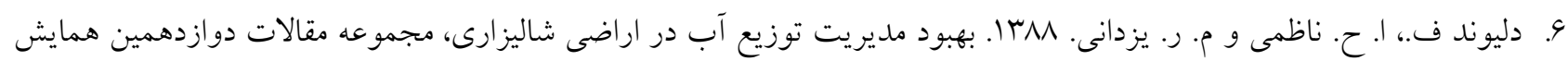

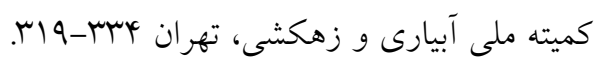

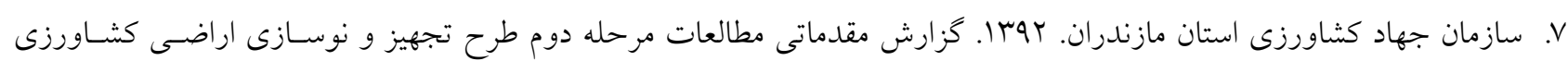

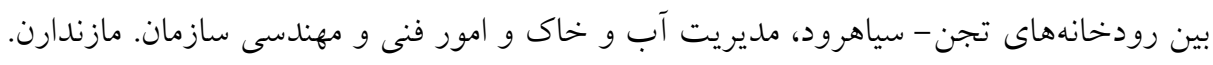

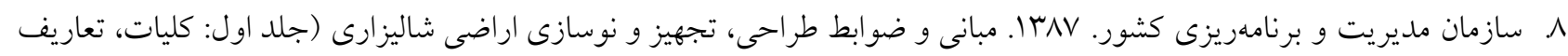

$$
\text { و مفاهيم بايه)، نشريه شماره ا-1-1: }
$$

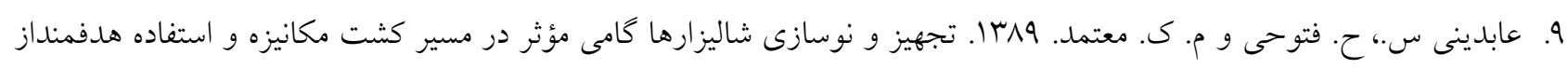

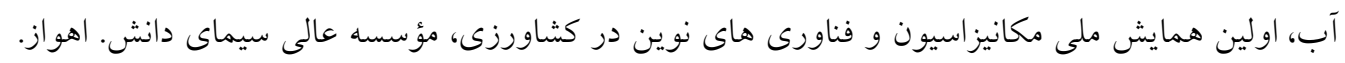

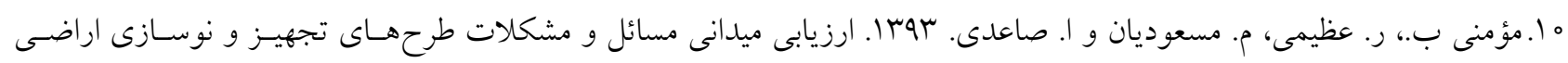

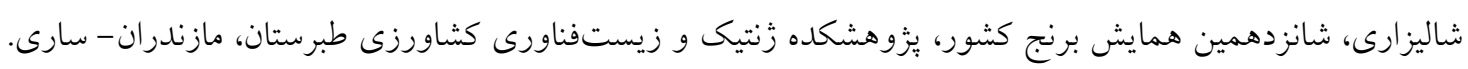

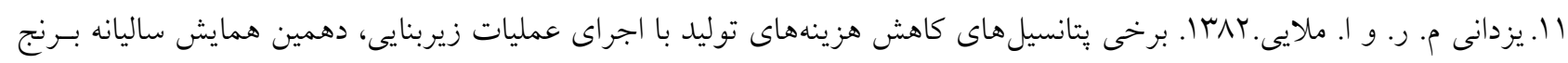
كشور، كيلان.

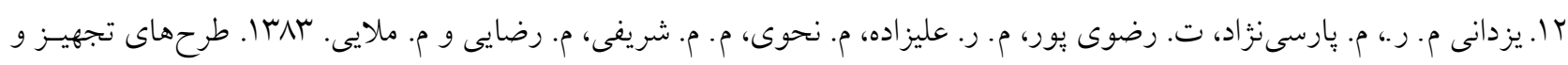

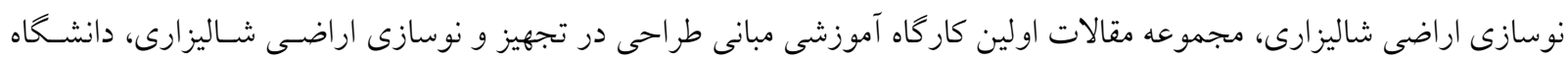
كيلان.

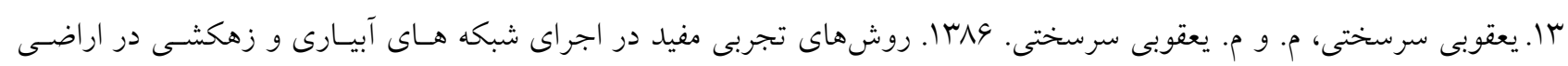

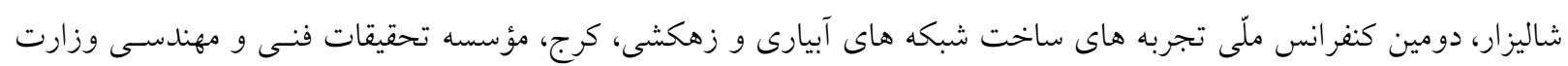
جهاد كشاورزى TrV-rMG 
14. Abernethy, C. L. 1990. Report No: H007823, Colombo, Sri Lanka: International Irrigation Management Institute (IIMI).

15. Barker, R, W. Coward, G. Levine and L. E Small. 1984. Irrigation Development in Asia: Past Trends and Future Directions. Cornell University, Ithaca, New York.

16. Clemmens, A. J., M. G. Bos and J. A. Replogle. 1984. Portable RBC flumes for furrows and earthen channels. Transactions of the ASAE 27(4): 1016-1021.

17. Frenken, K. and V. Gillet. 2012. Irrigation Water Requirement and Water Withdrawal by Country. FAO, Rome, Italy.

18. Gilfedder, M., L. D. Connell and R. G. Mein. 2000. Border irrigation field experiment. I: Water balance. Journal of Irrigation and Drainage Engineering 126(2): 85-91.

19. Lenton, R. L. 1984. Note on Monitoring Productivity and Equity in Irrigation Systems. Productivity and Equity in Irrigation Systems/edited by Niranjan Pant. Ashish Publishing house, New Delhi, India.

20. Makombe, G. and R. K. Sampath. 1998. An economic evaluation of smallholder irrigation systems in Zimbabwe. International Journal of Water Resources Development 14(1): 77-90.

21. Marikar, F., J. Wilkin-Wells, S. Smolnik and R. K. Sampath .1992. Irrigation system performance and its impact on crop productivity in Sri Lanka. International Journal of Water Resources Development 8(4): 226-234.

22. Molden, D. J. and T. K. Gates. 1990. Performance measures for evaluation of irrigation-water-delivery systems. Journal of Irrigation and Drainage Engineering 116(6): 804-823.

23. Oad, R. and R. K. Sampath. 1995. Performance measure for improving irrigation management. Irrigation and Drainage Systems 9(4): 357-370.

24. Seckler D., R. K. Sampath and S. K. Raheja .1988. An index for measuring the performance of irrigation management, systems with an application. Water Resources Bulletin of American Water Resources Association, Paper No. 87099.

25. Thakur, A. K., S. Rath, S. Roychowdhury and N. Uphoff. 2010. Comparative performance of rice with system of rice intensification (SRI) and conventional management using different plant spacing. Journal of Agronomy and Crop Science 196(2): 146-159.

26. Theil, H. 1966. Applied economic forecasting. In: Studies in Mathematical and Managerial Economics. Volume 4. North-Holland Publishing Company. Amsterdam, Netherlands.

27. Weller, J. A., E. B. Payawal and S. Salandanan. 1989. Performance assessment of the Porac River irrigation system. Asian Symposium on the Modernizations and Rehabilitation of Irrigation and Drainage Schemes, Development Academy of the Philippines, ODU/Hydraulics Res. Ltd., Wallingford, UK. 


\title{
Evaluation of Water Performance Delivery Performance Error Indicators in Development and Renovation Project of Paddy Fields
}

\author{
B. Moumeni ${ }^{*}$, M. Masoudian², M. Gholami² and A. Emadi²
}

(Received: August 9-2016; Accepted: October 14-2017)

\begin{abstract}
Over the years, since the beginning of the national and infrastructural project of Development and Renovation of Paddy Fields of Iranian Northern provinces, it has been essential to evaluate water distribution and delivery Performance of the project to get its feedback in the pursuit of the desired goals. However, the results of the evaluation of a system can reliable when they are based on quantitative indicators, not on personal opinions and empirical judgment. So, in this study, Total Error (TE) of performance of water delivery system, a statistical indicator, and its component including adequacy, water management capability and equity errors were calculated and compared for two concrete and earthen irrigation canals. This analysis was done based on calculating water demand and measuring the volume of delivered water between outlets during the irrigation season in the paddy fields of Esmaelkola of Joybar city, in 2015. According to the results, although the concrete channel $(0.28)$ had less error than the earthen channel $(0.43)$ and in the concrete channel, as compared to the earthen channel, the share of the components of adequacy and water management capability from the total error was dropped from $47 \%$ to less than $10 \%$, but the error in the water delivery of the concrete channel was still high due to the error in the equity of distribution, whose value was 0.25 ( $90 \%$ of the total error). Therefore, in order to reduce the performance error, after channel lining, it would be necessary to make fundamental changes in the intake and flow control structure in addition to the training of irrigators regarding water delivery based on water demand.
\end{abstract}

Keywords: Performance evaluation, Rice, Water delivery, Adequacy, Water management capability, Equity

1. Department of Agriculture, Payame Noor University, Tehran, Iran.

2. Department of Water Engineering, Sari University of Agricultural Sciences and Natural Resources, Sari, Iran.

*: Corresponding Author, Email: babak1172@yahoo.com 